\title{
O Direito Internacional Privado solucionando 'conflitos de cultura': os divórcios no Japão e seu reconhecimento no Brasil
}

\section{Claudia Lima Marques}

\author{
Professora Titular de Direito Internacional Privado da \\ Universidade Federal do Rio Grande do Sul, \\ Doutora em Direito pela Universidade de Heidelberge \\ Mestre em Direito Civil e Direito Internacional Privado pela \\ Universidade de Tübingen, Alemanba
}

\section{INTRODUÇÃO}

Anna Maria Villela afirmava que o divórcio pronunciado por um juiz estrangeiro, uma das questões mais antigas no Brasil, levou o nosso Direito Internacional PrivadoDIPriv. a uma evolução sem precedentes nesta matéria. ${ }^{1}$ Também Haroldo Valladão ${ }^{2}$ dedicou um de seus cursos na Academia de Direito Internacional de Haia à dissolução do casamento, demonstrando que, mesmo não conhecendo o divórcio até 1977, o Judiciário brasileiro

\footnotetext{
'VHLleld, Ana Maria. O divóncio no Direito Internacional Privado. Rio de Janeiro: Forense, 1980, p. 7 e 30.

${ }^{2}$ VALLAD AO, Haroldo. Conséquences de la difference de nationalité ou de domicile des époux sur les effets et la dissolution du marriage, in Recueil des Cours, 1962, t. 105, p. 75 e seg.
} 
sempre foi muito aberto ao reconhecimento de sentenças estrangeiras de dissolução do casamento, se pelo menos um dos cônjuges era estrangeiro. ${ }^{3}$

Efetivamente, a questão do divórcio esteve por muito tempo relacionada no Brasil a elementos culturais (e jurídicos) específicos, como à forte influência da religião católica no país a ponto de a indissolubilidade do casamento (até 1977) ${ }^{5}$ ou a sua dissolubilidade fazer parte integrante de nossas normas constitucionais (Art. 226, $\$ 6^{\circ}$ da Constituição Federal de 1988), logo, da ordem pública em DIPriv. A Aamosa Súmula $381,{ }^{7}$ sobre o não reconhecimento de divórcios em foros facilitatórios e por procuração, constitui-se entre nós no maior exemplo de combate à fraude à lei pessoal em nosso Direito Internacional Privado. ${ }^{8}$

Da mesma forma, internacionalmente, o divórcio foi responsável por muitas evoluções na teoria do direito internacional privado, desde a noção de fraude à lei, no famoso caso da princesa Baufremont de 1878 , como no que se refere à qualificação entre regras de fundo e regras de forma, da própria evolução da noção de ordem pública, posiriva e negativa, ${ }^{10}$ ao hoje concedido reconhecimento automático do

${ }^{3}$ Assim SAMPAIO, Pedro. Validade das Sentenças de Divórcio no Direito Brasileiro. Rio de Janeiro: Forense, 1973, p. 102. Veja em SAMPAIO, p. 89 e seg, também a reprodução da jurisprudência do Supremo Tribunal Federal antes da introdução do divórcio no Brasil.

${ }^{4}$ Assim SOUZA, Adalberto Pinentel Diniz de. Dissolução do vinculo conjugal, in Revista dos Tribunais, v. 741, jul. 1997, p. 747 e seg. (747-760).

${ }^{5}$ Por exemplo, a Constituição de 1964 afirmava: "Art. 175.A familia é constituída pelo casamento e terá direito à proteção dos Poderes Públicos. $\$ 1^{\circ} \mathrm{O}$ casamento é indissolúvel." in SAMPAIO, p. 102. ${ }^{6}$ VILLELA, p. 30.

${ }^{7}$ A Súmula (jurisprudência consolidada e uniformizada) do Supremo Tribunal Federal nx. 381 é a seguinte: "Não se homologa sentença de divórcio obtida por procuração, em país de que os cônjuges não eram nacionais", veja ROSAS, Roberto, Direito sumular-Comentários às Súmulas do STF e ST], Editora Revista dos Tribunais, Săo Paulo, 1991, p. 160 e 161, que explica: "Se os nubentes năo residem no país onde reçuerem o divórcio, porén, se habilitam por procuração, não se admite a homologação desse divórcio no Brasil, evidente caso de fraude à lei, principalmente quando os cônjuges residem no Brasil (Haroldo Valladão, Direito Internacional Privado, vol. 3/203)."

${ }^{8}$ Segundo BASSO TAMAGNO, Maristela. Da aplicafão do direito estrangeiro pelo juiz nacional, São Paulo: Saraiva, 1988 , p. 82 , a base da Súmula 381 foi a seguinte decisăo: "Casamento realizado na Itália e divórcio decretado no México. Sentença a que se denegou homologação. Ausência de prova de nacionalidade do marido e do domicílio de ambos os conjuges, nos dois paises." (STF Sentença Estrangeixa n. 1778-méxico, 1962, Reł. Min. Pedro Chaves).

${ }^{9}$ Assim ensina AUDIT, Bernard, Le caractère fonctionnel de la règle de conflit, in Recueil des Cours, 1984-HI, p. 348 e 349: "...la Cour de cassation déclara que la loi espagnole alors prohibitive du divorce était "contraire à la conception française actuelle de l'ordre public international qui impose la faculté pour un Français, domicilié en France, de demander le divorce..."

"Assinn ensina GAUDEMET-TALLON, Hélène. La désunion du couple en droit international privé, Recueil des Cours, 1991,1, t. 226, p. 30. 
divórcio praticamente sem exame da ofensa à ordem pública, ${ }^{\mathrm{t}}$ nos Estados da Unnião Européia. ${ }^{\text {i2 }}$

Na Alemanha, o famoso caso do casamento entre um espanhol solteiro e uma alemã divorciada em 1971 teve como base a inexistência da instituição do divórcio na Espanha e a conseqüuente proibição daquele casamento, o que foi considerado contra os direitos humanos e os Artigos 3 e 6 da Lei Fundamental de Bonn, resultando assim na evolução da ordem pública positiva com constitucionalização do Direito Intemacional Privado e modificação da EGBGB. ${ }^{13}$ Assim também foram os titos religiosos de divórcios, como o divórcio judaico, ${ }^{14}$ que forçaram o Judiciário na Alemanha a teconhecer a necessidade de uma 'tolerância funcional' entre estas entidades e o judiciário laico. ${ }^{15}$

Como ensina o meu mestre de Heidelberg, Erik Jayme, o respeito às diferenças culrurais é um valor na pós-modermidade e aparece com extrema clareza em matéria de formas de celebração e formas e causas de dissolução do casamento. ${ }^{\circledR 6}$ Cultura é o conjunto das formas típicas de viver de grandes grupos de pessoas, incluindo suas atividades, suas formas básicas de pensamento, de expressão e de valores, sua maneira de ver

"Veja, por todos, ESPLUGUES MOTA, Carlos, El divorcio internacional, Ed. Tirant to blanch, Valencia, 2003, p. 27 e seg.

12 Assim JAYME, Erik, O Direito Internacional Privado do Novo Milênio: a proteção da pessoa humana face à globalizaçāo, in Cadernos do Programa de Pós-Graduação em Dineito da Universidade Federal do Rio Grande do Sul-PPGDir./UFRGS, vol.1, n.1, maxço 2003, p. 85-97 e ANCEl, Bertrand e MUTR-WATT, Horatia, La désunion européene: le Règlement dit 'Bruxelles II', in Revue crit. dr. internat. privé, 90 (3) juillet-september 2001, p. 403-457.

${ }_{13}$ Veja sobre este caso e sua inluência na modificação e atualização da lei de introdução ao Código Civil alemão (EGBGB) e seu atual Art. 6, LABRUSSE, Catherine, Droit constitutionnel et le droit international privé en Allemagne fédérale à propos de la décision du Tribunal Constitutionnel fédérale du 4 mars 1971, Rev. Crit. dr. internat. privé, 1974, p.l e seg. Veja também BUCHER, Andreas, La famille en droit international privé, Recueil des Cours, tome 283 (2000), p. 9 e seg.

${ }^{14}$ Sobre o tema o divórcio judaico e a importânica de conseguir a carta-get, veja EINHORN, Talia. Jewish Divorce in the International Arena, in BASEDOW, J. Private Law in the international Arena-Liber Amicorum Kurt Siebr, Haia: T.M.C. Asser Press, 2000, p. 135 e seg,

${ }^{15}$ Assim reproduz Erik Jayme uma decisão de 1994, a qual afirma que deve o 'tribunal religioso do rabinato' promover o divórcio de judeus nacionais de Israel em solo alemão, havendo possibilidade de reconhecimento, mas não de 'atuação' do Judiciário alemão pra realizar o divóxcio segundo queriam as partes, segunda a lei israelt:"Eine solche vom jüdischen Recht geforderte Mitwirkung des Rabbinatsgerichts, das das Vorliegen der Scheidungsvoraussetzungen feststellt, ist eine Tätigkeit, die, weil der Rabbiner als Geistlicher tätig wird und sein Mitwirken Teil einer religiösen Handlung ist, dem deutschen Rechtssystetn völlig wesensfremd ist und von einera deutschen Gericht nicht geleistet werden kann."(KG 11.1.1993, FamRZ 1994, p. 839), in JAYME, Erik, Religiöses Recht vor staatlichen Gerichten. Heidelberg: C.Winter, 1999 , p.1. Veja também no mesmo sentido decisão de 1998, KG 27.11,1998, in IPRAx 2000, p. 126-128 eseu comentário por HERFAFRT, Christoph, Scheidung nach religiösen Recht durch deutsche Gerichte, in IPRAX 2000, p. 101-103.

' Jayne, Religiöses Recht, p. 35 e 36. 
o mundo. Em sentido lato, cultura é o tesultado da atuação do homem no mundo, aquilo que é diferente da natureza: o mundo cultutal é o mundo realizado pelo homem, inclusive suas normas postas e seguidas no dia a dia de uma sociedade. ${ }^{17}$ Assim, apesar da imigração, os grupos culturalmente ligados, os grupos étnicos e teligiosos, como ensina Erik Jayme, ${ }^{18}$ integram-se nas novas pátrias, como os grupos de descendentes de japoneses no Brasil, mas preservam sua língua, sua religião, seus costumes, seu modo de ver o mundo... sua cultura!

O Direito Comparado sempre separou as 'famílias' de direito justamente com base nestas 'práticas' e visões culturais diferentes do direito. ${ }^{19}$ Zweigert e Kötz consideram que é característica da 'família de direito do extremo oriente' (der fernöstliche Rechstkreis) a procura da harmonia pela solução não-conflitual dos litígios e uma forte hietarquia social e intetna na família. ${ }^{20}$ Em matéria de divórcios, o tema é solucionado longe do Judiciário, que somente é usado quando o consenso não pode ser atingido. Os efeitos do divótcio são tratados em família e muito raramente com a ajuda de mediadores, sendo que o advogado praticamente não tem nenlıuma atuação ou função nestes momentos 'privados'. ${ }^{21}$

17 Definição de cultura baseada na definição da encinclopédia Brockbause Lexikon, Band 10, DTV, Wiesbaden, 1982, p. 182. Veja também HÖFFE, Otfited, Lexikon der Ethik, Beck, Munique, 1986, p. 140: "Natur den vom Menschen geschaffenen Lebensraum." Em portugués veja interessante trabalho de MARTINS, Estevão Chaves de Rezende, Relaçôes Internacionais-Cultura e Poder, IBRI/UnB, Brasilia, 2002, p. 43: "Cultura tornou-se uma incógnita no panorana mundial contemporâneo. Os antropóplogos sempre definiram cultura como 'o modo de vida de um povo'." Veja as linahs atuais do direito que partem da cultura, na obra de Kahn, Paul W., The cultural study of Law-Reconstructing legal scholarsship, University of Chicago Press, Chicago, 1999, p. 1: "The culture of law's rule needs to be studied in the same way as other cultures."

${ }^{18}$ Assim JAYME, Erik, Societá Multiculturale e nuovi sviluppi del Diritto internazionale privato, in Il Diritto dei nuovi mondi, Cedam, Milão, 1994, p. 344 (343-356).

${ }^{19} \mathrm{Veja}$, por todos, RHEINSTEIN, Max, Einfübrung in die Rechstvergleichung, 2.Ed., Beck, Murique1987, p. 81 e 82 mencionando as práticas originais das sociedades asiáticas ao lado das sociedades latinoameticanas.

${ }^{20}$ Assim ZWETGER', Konrad e KÖTZ, Hein, Einführung in die Rechstvergleichung auf dem Gebiete des Privatrechts, 2. ed., Mohr, Tübingen, 1984, p. 406 (\$28II) e especifico sobre Japão, p. 416 e 417 (\$ 28,IV).

2s ZWEXGERT/KÖTZ, p. 417 (\$28 IV). 
O grande comparatista, René David, observa que apesar da 'ocidentalização' do dircito japonês a partir de 1868, os 'giri' (regtas de comportamento socialmente tradicionais), os códigos de honra puramente costumeiros e uma 'ausência da idéia de direito' como o conhecemos no ocidente continuam a 'reger' os comportamentos no Japão, ${ }^{22}$ e conclui: "Mas se as instituiçôes japonesas estão totalmente ocidentalizadas, se as técnicas jurídicas estão modernizadas, mesmo assim a sua aplicação na atmosfera cultural japonesa demonstra ainda a atualidade profunda e viva dos princípios tradicionais." 23

Apesar de respeitáveis aurores franceses concluírem pela existência de um 'conflito de civilizações, ${ }^{24}$ principalmente em casos de direito internacional privado envolvendo pessoas com a visão ocidental de direito ou pessoas de países islâmicos, preferirei neste trabalho a expressão do mestre de Heidelberg, Erik Jayme, que ao tefletir sobre o direito de família na sociedade multicultural do ocidente de hoje, preferiu denominá-los 'conflitos de cultura' e matcar a identidade cultural de indivíduos vindos do oriente, $A$ sia e países islâmicos e suas coletividades nos paises de imigração, como o Brasil e considerar que é uma das finalidades do Direito Internacional Privado atual dat respostas diferentes e eqüirativas à presença de grupos culturalmente diferentes em um mesmo país, resolvendo este denominado 'conflito de leis', que é em verdade um conflito de 'culturas' jurídicas.

O objetivo deste breve rrabalho é, pois, refletir sobre a pesquisa com 30 casos envolvendo divórcios japoneses no Supremo Tribunal Federal (STF) de 1975 a 22 de agosto de 2002, que foi realizada em conjunto com alunas da graduação e pósgraduação para servir de base à trabalho da Profa. Dra. Yuko Nishitani apresentado em 2002 e que foi publicada na Revista da Faculdade de Direito da UFRGS em setembro de 2002, na Edição especial justamente em homenagem à Cooperação entre a Faculdade de Direito da Universidade de Tohoku, Sendai (Japão) e a Faculdade de Direito da UFRGS. ${ }^{25}$

\footnotetext{
22 DAVID, René e JAUFFRET-SPINOSI, Camille, Les grand's systèmes de droit contemporains, 9.ed., Dalloz, Paris, 1988 , p. 614 e 615.

23 DAVID/JAUFFRET-SPYNOST, p. 627: "Mais si les institutions japonaises sont totalement occidentalisées, si les techniques juridiques sont modernisées, néanmoins leur application dans l'atmosphère culturelle japonaise révèle encore l'actualité profonde et vivante des principes traditionnels."

${ }_{24}$ Aqui a obra principal é o interessantíssimo curso de Haia de DÉpREZ, Droit international privé et conflits de civilisations. Aspects mèthodologiques (les relations entre systèmes d'Europe occidencale et système islamique en matière de statut personnel), in Recuell des Cours, vol. 211 (1988-IV), p. 9 e seg.

25 MARQUES, Claudia Lima, JACQUES, Daniela e SCHMTTz, Maitê, Pesquisa de casos envolvendo divórcios japoneses no Supremo Tribunal Federal, in Revista da Faculdade de Direito da UFRGS, Edição especial em homenagem à Cooperação entre a Faculdade de Direito da Universidade de Tohoku, Sendai (Japão) e a Faculdade de Direito da UFRGS, setembzo 2002, p. 176 a 219.
} 
Minha hipótese de trabalho é que aqueles 30 casos (23 decisões monocráticas do presidente do Tribunal e 7 acórdãos do Tribunal Pleno) representam uma amostra significativa de como é entendida a instituição do reconhecimento de sentenças pelo Supremo Tribunal Federal. Isto é, uma amostra da forma bastante flexivel e aberta para solucionar eventuais 'conflitos culturais', em especial com países de origem de nossos imigrantes majoritátios, como o Japão, teconhecendo uma equivalência funcional em atos privados de divórcio consensual, registrados apenas administrativamente no Japão e o divórcio judicial como é aqui conhecido. Dividirei minha análise em duas partes, uma primeira dedicada a compreender os tipos de divórcio segundo o direito japonês e analisar a base legal brasileira e uma segunda dedicada a análise do processo de delibação concentrado no STF e dos casos levantados.

\section{I - DIVÓRCIOS DECLARADOS NO JAPÃO E O DIREITO BRASILEIRO ATUAL: UM DIVÓRCIO CONSENSUAL E PRIVADO RECONHECÍVEL SEGUNDO O DIREITO BRASILEIRO?}

Segundo o Prof. Dr. Erik Jayme, da Universidade de Heidelberg, Alemanha, em seu artigo sobre Direito Comparado pós-moderno, ${ }^{26}$ o direito comparado pós-moderno estaria mais interessado no diferente, no fluído e especial, aquilo que divide e caracteriza o diteito, no atual e específico de cada ordenamento jurídico, a tespeitar a identidade social e cultural de cada povo. ${ }^{27}$ Nesta linha, mister observar que Btasil e Japão apresentam duas culturas, dois povos diferentes, dois sistemas jurídicos bastante distintos. Escolber como objeto de pesquisa estas 'diferenças', ${ }^{28}$ especialmente em Direiro Internacional de Família, é a nossa finalidade, assim como verificar se estas 'diferenças' podem ser superadas, contornadas ou assimiladas de forma a permitir o reconhecimento de uma mesma funcionalidade ou se estas diferenças significam alguma espécie de ruptura de fundo, violação de princípios basilares ou ofensa ao ordenamento jurídico do outro país.

O divórcio realizado em um país, por exemplo no Japão, por um nissei brasileiro (segunda getação de imigrantes japoneses), que lá reside para trahalhar em uma fábrica, tem de ser reconhecido em outro país, por exemplo, no Brasil, onde o outro cônjuge reside com os filhos ou onde é seu domićlio. Este divórcio determina a modificação do estado civil destes imigrantes, brasileiros ou japoneses, permite um novo casamento, consolida ou

\footnotetext{
${ }^{26}$ Veja J AYMFs, Erik, Visões para uma teoria pós-moderna do direito comparado, in Revista dos Tribunais (São Paulo), nr. 759, p. 24 a 40.

${ }^{27}$ Veja meu artigo, Notas sobre o sistema de proibição de cláusulas abusivas no Código Brasileiro de Defesa do Consumidor (Entrea tradicional permeabilidade da ordem jurídica e futuro pós-moderno do direito comparado), in RTDC vol. 1, jan/mar. 2000 , p. 13 a 58.

${ }^{28}$ JAYME, RT 759, p. 25: "A minha Tese principal éa seguinte: Odireito comparado moderno perseguia o objetivo, de determinar, de encontrar o que era comum, igual (das Gemeinsame), eque apenas superficionalmente podia aparexer eser percebido de forma diversa, nos também aponas sutperficional mente diversos, sistemas de Direito do mudo. O dineito comparado pós-modernoprocura, ao contránio, o que divide(das Trennende), as diferenças (die Unterschiede)."
} 
determina a partilha de bens, localizados no Brasil ou no Japão e leva à regulação dos deveres alimentates entre cônjuges e em telação à eventual prole. ${ }^{29}$ Mister, pois, analisar os tipos de divórcio japoneses e comparar com as normas brasileiras aplicadas nestes casos.

\section{A - OS TIPOS DE DIVÓRCIO NO DIREITO JAPONÊS E SUA PROBLEMÁTICA}

Em seu belo artigo, a colega de Sendai, Profa. Dra. Yuko Nishitani ${ }^{30}$ destaca a importância de compreender os tipos de divórcio do direito japonês e toda a problemática que estes tipos, em especial os consensuais podem trazer. Efetivamente, como ensina Muir Watt, ${ }^{3 !}$ os modelos familiares são afirnações da cultura, do modo de ver os direitos humanos, e, em especial, a atual desagregação da família nas relações privadas internacionais é um grande desafio para o Direito Internacional Ptivado do mundo globalizado. Gannagéż observa que a neutralidade 'savigniana' do Direito Internacional Privado, em especial quando populações de origens e tradições culturais diferentes estão em contato, começa a ser substituída por soluções diferenciadas e tópicas, servindo-se muitas vezes da exceção de otdem pública, que pressupõe um exame caso a caso e do tesultado da aplicação do direito estrangeiro indicado aplicável. Em matéria de reconhecimento de direitos adquiridos ou constituídos sob a égide da lei estrangeira, geralmente utilizam-se os países de uma noção de ordem pública 'menos exigente', mais flexível e tolerante com as diferenças culturais nos dias de hoje. ${ }^{33}$ Vejamos o que ocorre no cáso deste encontro de culturas brasileita e japonesa.

\section{CULTURA 'JURÍDICA' E OS DIVÓRCIOS CONSENSUAIS NO JAPÃO}

O mestre Erik Jayme, ao receber o vítulo de doutor honoris causa pela Universidade Federal do Rio Grande do Sul, Porto Alegre, analisou este mesmo levantamento jurisprudencial realizado na jurisprudência do Supremo Tribunal Federal, e conclui que os

\footnotetext{
${ }^{29}$ Assim ensina FERNANDEZ ARROYO, Diego et alli, Derecho Internacional prlvado de los Estados del Mercosur, Zzd. Zavalia, Buenos Aires, p. 749 e seg.

3. NISHITANI, Yuko, Privat- und Scblichtungsscheidung deutscher Staatsangeböriger in Japan und die Scheidungsannerkennung in Deutscbland, in IPRAX 2002, p. 49-53.

${ }^{31}$ MUIR WATT, Horatia, Les modeles familiaus à l'épreuve de la mondialisation (aspects de droit international privé), Arch. phil. droit 45 (2001), p. 271 (pp. 271-284).

${ }^{32}$ GANNAGE, Lena, La pénétration de l'autonomie de la volonté dans le droit international privé de la famille, Revue critique de droit international privé 81 (1992), p. 427.

3. Assim GANNAGË, p. 427
} 
imigtantes japoneses, mesmo aqueles com domicilio permanente no Brasil, preferiram o foro japonês ou melhor, o estilo japonês de divorciar-se consensualmente e de maneira privada, a constituir um foro seguro, discreto, um foro-lar (Heimatforum), justamente por questôes culturais. Tal preferência, mesmo em imigrantes de segunda geração ou imigrações de mais de 40 anos, conclui o mestre, ser exemplo da 'dimensão cultural' do direito, a ser respeitada em especial pelo direito internacional privado. ${ }^{34}$ Seria, pois, um exemplo de respeito à autonomia de vontade, como direito básico também en direiro internacional de familia, a busca do foro e da lei mais adaptada ao sentimento cultural do indivíduo imigrante ou de nacionalidade diferente, sempre que não houvesse fraude à lei ou ofensa à ordem pública. ${ }^{35}$

Habermas relembra que, em se tratando de multiculturalismo ou sociedades multiculturais, como a brasileira, a luta dos grupos sociais 'diferentes', como os grupos de raças diffrentes ou de imigrantes (por exemplo, os grupos afro-americanos ou os grupos de imigrantes nos EUA), é pelo seu reconhecimento como grupo a merecer tratamento diferenciado, mais flexível ou tolerante no Estado Democrático de Direito. ${ }^{36}$

Face a cultura japonesa, - de resolver de forma interna e discrera- os prohlemas familiares ${ }^{37}$ não é de espantar que existam no país duas 'formas' privadas consensuais ou mediadas de dissolução do casamento, sem qualquer presença do Estado no que se refere à

${ }^{34}$ Veja Kulturelle Dimension des Rechts, in RABELSZ 67 (2003), p. 226 e seg. e conferência inédita na UFRGS no prelo. Veja JAYME, Erik. Direito Internacional Privado e Cultura Pós-Moderna, in Cademos do Programa de Pós-Graduação em Direito da Unizersidade Foteral do Rio Grandedo Sul-PPGDir./UFRGS, vol.1, n.1, março 2003 , p. $59-68$.

${ }^{35}$ Segundo GANNAGÉ, p. 451, é esta nova 'autonomia da vontade 'en direito de farnilia internacional uma opção consciente dos legisladores para alcançar uma maior harmonia internacional de soluçöes: "L'autonomie de la volonté paraît certes constituer une voie particulièrement indiquée pour réaliser cette harmonie."

${ }^{36}$ Assim estudo de HABERMAS, Jürgen, Struggles for Recognition in the Democratic Constitutional State, in Multiculturalism-Examining the politics of recognition, TAYLOR, Charles et alli, Princeton University Press: Princenton, New Jersey, 1994, p. 107 a 148, onde o autor pergunta: "Can a theory of rights that is so individualistically constructed deal adequately with struggles for recognition in which it is the articulation and assertion of collective identities that seems to be at stake?" (p. 107).

${ }^{37}$ Assin tambén FROMONT, Michel, Grands systèmes de droit étrangers, 2. ed., Dalloz, Paris, 1994, p. 134 e 135 . 
decharação de vontade, que é apenas comunicada através do registro a posteriori no cadastro administrativo do prefeito ou do distrito ou vila rural (Art. 1 e 16 do Kosekibô). ${ }^{38}$

Efetivamente, o Código Civil Japonês (Kasai Geppô) prevê, do Art. 763 ao Art. 768, estas formas de divórcio consensual, seja por aceitação simples de uma das partes da 'declaração de divórcio' pelo outro (art. 765), ${ }^{39}$ seja por mediação por tetceiro, em casos mais complexos, seja mediação voluntária ou obrigatória (que Nishitani denomina Schlichtungs. und $Z$ wangschli-chtungsscheidung $)^{40}$. O divórcio judicial, com auxílio do juiz, está previsto nos Art. 770 a 791 e é eferuado frente ao Tribunal de família. O Art. 819 do Código civil japonês estabelece as regras sobre guarda de menores e registro no cadastro de farnilia. ${ }^{41}$

Interessa-nos aqui as diferenças culturais. Para nós, brasileiros, acostumados ao litígio e à discussão da culpa no divórcio e a longas e amplas ações de separação e de divórcio onde todos os detalhes da vida em comum pregressa são examinados, chama a atenção a dissolução do casamento poder ser feita por simples 'negócio jurídico' registrado após em foro administrativo. No Japão, porérn, a aceitação deste tipo de divórcio é enorme, totalizando as formas de divórcio consensual mais de $90 \%$ dos casos. Assim, em 1999, 91,46\% dos divórcios tealizados no Japão foram divórcios "privados", exrrajudiciais conforme determina o $\$ 764$ c/c $\$ 739$ do Código Civil Japonês (Kasai Geppô), já 7,73\% dos divórcios ocorreram por arbitragem/mediação e somente $0,81 \%$ através de decisões judiciais stricto sensu. ${ }^{42}$ En seu texto de 2002, Nishitani adiciona ainda mais dados, informando que, em 1997 e 1998, $90,93 \%$ dos divórcios no Japão eram privados, somente $8,24 \%$ ocorreram por mediação voluntária e $0,4 \%$ por mediação imposta e $0,80 \%$ apenas eram divórcios judiciais. ${ }^{43}$

\footnotetext{
${ }^{38}$ Segundo gentil tradução de Tomoko Gaudioso, o texto do Art. 1 do Koseki bou é: Art. 1 [ Controle e administraçào referente ao cadastrol, $\mathrm{S1}^{\circ}$. O serviço referente ao cadastro de família é efetuado pelos órgãos estabelecidos por prefeitos, representante do distrito e por representantes das comunidades rurais(vilas)." Já Nishitani, IPRAX 2002, p. 49, denomina esta lei de Lei sobre o registro familiar (Gesetz über das Familienbuch) e kosekihô, que aqui utilizaremos.

${ }^{39}$ A gentil tradução de Tomoko Gaudioso deste texto é a seguinte: "Art. 765 [A aceitaçäo da declaração de divórcio] \$1. A aceitação da decłaração de divórcio somente ocorrerá após verificar que o mesmo não viola o $\$ 2$ do Art. $739, \$ 1^{\circ}$ do Art. 819 e outras lejs. $\$ 2^{\circ}$. Se a aceitação da declaração for efetuada por vício, omitindo o que fó estabelecido no $\$ 1^{\circ}$, mesmo assim, o seu efeito permanecerá."

40 NISHITANI, IPRax 2002, p. 50.

${ }^{41}$ Veja,por todos, MARUTSCHKE, Einfübrang in das japanische Recht, Munique, Beck, 1999, p. 2 e seg.

${ }_{22}$ Dados levantados por Yuko Nishitani, em 1999, em sua palestra na UFRGS, veja Jinkô Dôtai Chôsa 1999 (c//wwwdbtk.mhw.go.jp/toukei/data/010/1999/tokeihyou/0002674/ t0048025/ml...)

4. NISHITANI, YPRax 2002, p. 49.
} 
São estes divórcios "privados" japoneses que devem ser reconhecidos no Brasil e aparecem em 20 dos 30 casos analisados pelo Supremo Tribunal Federal em nossa pesquisa. ${ }^{44}$ Assim interessa-nos saber se há realmente esta natureza "admimstrativa" visualizada pelo STF nos casos ou se, em contrário, a sua natureza "privada" impediria o seu reconhecimento no Brasil.

De outro lado, no Brasil, o divórcio, como instituição, foi uma das mais polêmicas; instituição desconhecida no ordenamento jurídico brasileiro até 1977 , alcançou hietarquia constitucional (sua proibição e sua liberalização), sofreu vários limites e integra hoje, sem dúvida alguma, a ordem pública em DIPriv. ${ }^{45}$ Dai a importância de aprofundarmos a análise de uma eventual violação de nossa ordem pública por estes tipos de divórcio.

\section{AS NORMAS JAPONESAS SOBRE DIVÓRCIO E OS PROBLEMAS DE SUA PRÁTICA}

Mister inicialmente examinar algumas normas japonesas de Direito Internacional Privado, na lei especial de DIPriv. denoninada Horei ${ }^{46}$ Segundo o Art. 3 da Horei, a capacidade das pessoas (no caso os japoneses ou brasileiros que divorciam-se no Japão) é regulada pela lei de sua nacionalidade, japonesa ou brasileira. ${ }^{47}$ Neste sentido, telembre-se que muitos dos nissei brasileiros, que retornam para o Japão e lá se divorciam dos cônjuges domiciliados no Brasil, são brasileiros e não mais japoneses segundo as leis de nacionalidade japonesas, dai poder ser aplicado a este divótcio a lei brasileira. Quanto à forma, o Horei apresenta uma regra geral em seu Art. 8 que manda aplicar a lei principal (lex causae), a qual regulará os 'efeitos do negócio jurídico'. ${ }^{48}$ Neste caso, se o divórcio privado de um nissei brasileiro for considerado pelo STF como apenas um problema de forma e não como de mérito, aplicável é a lei principal do divórcio (lex causae), a japonesa ou a brasileira.

\footnotetext{
${ }^{44} \operatorname{Em} 20$ dos 30 casos, o divórcio foi declarado de forma consensual e registrado por ato administrativo, este reconhecidos pelo STF.

${ }^{25}$ Veja DOLINGER, Jacob, Evolution of principles for resolving conflicts in the field of contracts and torts, in Recueil, vol. $283(2000)$, p. 291 e seg.

"Utilizarei a tradưção da Horei (Gesetz betreffend die Anwendung der Gesetze) realizada pelo Instituto Max-Planct de Hamburgo, in KROPHOLLER, Jan et alli, Aussereuropäische IPR-Gesetze, Ed. DNotI/Max Planck-Institut, Kamburgo, 1999, p. 308 a 318.

${ }^{47}$ Horei, in KROPHOLLER, p. 308.

${ }^{4 B}$ Horei, in KROPHOLLER, p. 310.
} 
A lei principal que regula os divórcios realizados no Japão está determinada pelo Art. 16 do Horei. Aplicável seria a lei que regula o casamento (envio para o art. 14 do Horet), mas se um dos cônjuges é de nacionalidade japonesa ou possui à época do divórcio sua residência habitual no Japão, aplicável é a lei japonesa. ${ }^{49}$

Em sua palestra de 2001, a professora Nishitani resumiu as regras sobre o Divórcio no Direito Japonês da seguinte forma:

"O Código Civil Japonês (CCJ, Kasai Geppô) prevê o Divórcio privado e o divórcio judicial. A lei sobre Decisões em Matéria Familiar (LDMF, kaji shinpanhô) prevêo divórcio arbitral (administrativo) voluntário e o divórcio arbitral imperativo. Assim temos: (1) Divórcio privado (\$S 764 e 739 CCJ) $\rightarrow$ Deve ser registrado no "registro familiar"(koseki) conforme a Lei sobre o Registro Familiar (kosekihô); (2) divórcio arbitral é feito no tribunal familiar (administrativo) (Prioridade do arbitramento por mediadores em caso de não consenso: Art. 18, 1LDMF);(3) divórcio arbitral imperativo (sobre a base do arbitramento e mediação) frente ao Tribunal (administrativo) de Família (Art. 24 LDMF) $\rightarrow$ Há possibilidade de recurso; (4) Divórcio Judicial frente ao Juiz distrital (Processo normal segundo o Artigos $1 \mathrm{e}$ seguintes da Lei processual sobre processos envolvendo direitos individuais-LPDI, jinji soshô tetsuzukihô), quando um dos motivos de divórcio do $\$ 770,1$ CCJestá presente. Há um maior espaço de convencimento e decisão para o Juiz, mas a previsibilidade da decisão é pequena."

Yuko Nishitani, em sua palestra na UFRGS em de 2001, assim também concluia que, caso um dos 220 mil brasileiros que vivem atualmente no Japão queira divorciarse, será possivelmente declarado aplicável para este divórcio o direito japonês, face aos elementos de conexão escolhidos pela lei japonesa. ${ }^{50}$

Mister, pois, destacar as críticas que os próprios autores japoneses tecem com referência ao direito japonês do divórcio consensual. Yuko Nishitani alerta que, como a declaração de divórcio inicia de forma unilateral com um formulário (Scheidungsformular), preenchido geralmente pelo marido e como os japoneses não conhecem a assinatura, mas se utilizam para esta função de carimbos, há muita probabilidade de falseamento desta declaração de 'aceitação' do divórcio. A

\footnotetext{
49 "Art. 16. Whescheidung] die Bestinmungen des Art. 14. gelten entsprechend füz die Ehescheidung. Ist jedoch einet der ehegatten Japaner und hat seinen gewöhnlichen Aufenthalt in Japan, so richtet sich die Scheidung nach japanischen Recht." Horei, in KROPHOLLER, p. 313.

${ }^{50}$ Assim afirma Yuko Nishitani: "A lei aplicável ao divórcio (estatuto do divórcio) segzundo o Direito Internacional Privado japonês é a seguinte: Art. 16,1 da Lei de Direito Internacional Privado/Horei, que apresenta uma conexăo em cascata $\left(1^{\circ}\right.$. elemento de conexão: a lei nacional comum; $2^{2}$ conexão: a lei do lugar de residência habitual comum; $3^{2}$ conexão: a lei mais conectada com o caso concreto/ lei mais próxima do caso) e Art. 16,2 Horei: Se um dos cônjuges ten a nacionalidade japonesa e a sua residência habitual no Japão, aplicar-se-á a lei japonesa (denominada cláusula de "favor japonês")."
} 
ponto de existir um instrumento para evitar que um cônjuge possa 'declarar' o divórcio consensual sem o consentimento ou conhecimento do outro. O problema do falseamento é tão sério que, desde 1952, o Ministério da Justiça desenvolveu um diretiva, a qual permite a qualquer dos cônjuges realizar uma declaração no Registro de Familia ou Corte familiar denominada "Declaração cautelar de não aceitação da declaração de divórcio privado' (vorsoglichen Antrag auf Nichtannabme des Scheidungsformulars), pata evitar ual perigo. ${ }^{51}$ Informa a autora que, anualmente, cerca de 25 mil pessoas fazern uso deste instrumento preventivo no Japão. ${ }^{52}$

A referida autora vai mais longe, afirmando que mesmo se o cônjuge mulher realmente consentir na declaração de divórcio do marido, pode ela estar sendo tratada de forma 'abusiva' aos olhos ocidentais, pois nesta declaração a parte econômica da dissolução não é tratada ou se tratada, na maioria das vezes, é com renúncia a direitos patrimoniais. ${ }^{53}$ Para se ter uma idéia da força desta observação da autora japonesa, mister ponderar que segundo o Art. 762 do Código Civil japonês, o regime de bens legal já é o da separação de bens e, anualmente, apenas 15 casais optam no Japão por outro regime de bens mais favorável às mulheres. ${ }^{54}$ Informa também que, em $50 \%$ dos divórcios privados, os alimentos para a mulher não são concedidos e que ern $80 \%$ dos divórcios, o tema dos alimentos para os filhos sequer é tratado nesta declaração de divórcio $!^{55}$ Estas estatísticas impressionam se pensarmos que se tratam de divórcios diretos, sem prévia separação judicial e partilha.

Sendo assim Yuko Nishitani defende, em seu artigo de 2002, que as 'declarações de divórcio' consensual mesmo que registradas administrativamente não equivalem funcionalmente às decisões judiciais ou sentenças (Urteil) ou aos atos offciais (Hobeitsaktes), como é exigido pelo direito alemão (\$328 ZPO), que está analisando. ${ }^{56}$ A mesma conclusão poder-se-ia chegar analisando-se o direito brasileiro. Lembra que a doutrina alemã reconhece estes divórcios apenas como 'negócios juridicos'. ${ }^{57}$

${ }^{51}$ NISHI'TANI, IPRax 2002, p. 49.

52 NISHITANI, IPRax 2002, p. 49.

${ }^{3}$ NISHITANI, IPRax 2002, p. 49.

54 NISHYTANI, IPRax 2002, p. 49.

5SISHITANI, YPRax 2002, p. 49 e nota de estatística de MIZUNO de 1978, nota 9.

56 NISHITANI, IPRax 2002, p. 52.

57 NISHITANI, IPRax 2002, p. 52, citando os principais comentaristas Kegel/Schurig, Palandt/ Helderich, Soergel/Schurig e Staudinger/Spelbernberg e decisão que não reconheceu um divórcio privado japonês, pois aplicável era a lei alemã, BGH 21.2.1990 (BGHZ 110,267). 
Note-se que Erik Jayme $e^{58}$ destaca a abertura cultural que este reconhecimento também representa, pois a Corte Federal Alemã reconheceu mesmo validade a um divórcio baseado em mútuo consentimento de dois tailandeses, declarado por negócio jurídico, mas em território alemão! Segundo o mestre, é o revival da autonomia de vontade que ganha espaço no direito internacional privado de família, un desenvolvimento que deve ser saudado e não combatido, se respeita a identidade cultural dos envolvidos e respeita os direitos humanos dos envolvidos. ${ }^{59}$

Segundo Yuko Nishitani, o divórcio mediado preenche, sim, funcionalmente os requisitos, pois o mediador cuida para que o cônjuge mais fraco receba um tratamento econômico correto; assim também um divórcio frente ao juiz japonês pode e deve ser reconhecido en outros países. ${ }^{69}$

Em resumo, é grande a probabilidade que se aplique a lei japonesa aos divórcios de brasileiros de origem japonesa residentes habitualmente no Japão e que este seja um divórcio privado, consensual, por declaração em formulário. Melhor seria que nestes easos, quando o cônjuge sabe que deverá reconhecer o divórcio no Brasil, que se escolhesse a via do divórcio por arbitragem/mediação ou judicial, pois estes não teriam nenhum problema para serem reconhecidos pelo Supremo Tribunal Federal.

\section{B - COMPARANDO AS NORMASEA FUNÇÃO DOS DIVÓRCIOS PRIVADOS JAPONESES COM OS DIVÓRCIOS BRASILEIROS : RECONHECIMENTO OU VIOLAÇÃO DA ORDEM PÚBLICA?}

Efetivamente, as observações realizadas por Yuko Nishitani sobre as várias possibilidades de fraude e as dificuldades referentes aos divórcios consensuais japoneses relevam um problema sério para determinar se há ou não ofensa a nossa ordem pública e qual a natureza destes divórcios. O Supremo Tribunal Federal tem considerado todos estes casos como divórcios 'administrativos' e os reconhecido sem maiores indagações, sendo que a problemática da ordem pública sequer é mencionada. nos 30 casos analisados, o único motivo usado para recusar homologação foi a competência absoluta do juízo brasileiro, envolvendo divórcio de nacionais japoneses domiciliados no Brasil, mas profenido no Paraguai. ${ }^{61}$ Dai a necessidade de passarmos ao exame das normas brasileiras sobre o assunto.

\footnotetext{
58 JAYMF, Società Multiculturale, p. 351, citando o caso BGH, 14.10.1981, BGHZ 82,p. 34, publicado in IPRAX 1983, p. 37 e comentado por Gerhard Kegel, in IPRAX 1983, p. 22 e seg.

59 Assim JAYME, Società Multiculturale, p. 356. Veja sobre o tema também GANNAGE, p. 425 e seg.

60 NISHITANI, IPRax 2002, p. 53.

Gi MARQUES/JACQUES/SCHMIDT, p. 218-219.
} 


\section{AS NORMAS BRASILEIRAS PRINCIPAIS SOBRE DIVÓRCIO}

O novo Código Civil de 2002 regula a dissolução do casamento pelo divórcio nos Art.1.571 e seguintes ${ }^{62}$ As regras determinam os cfeitos da separação e do divótcio, no que se refere ao nome, a guarda dos filhos, direito de visitas, aos alimentos ao cônjuge e aos fillos e a partilha de bens ${ }^{63}$ Preocupa-se também com o registro do estado civil de divorciado, afirmando: "Art. 10. Far-se-á averbação em registro público: $I$ - das senten ças que decretarem a nulidade ou anulação do casamento, o divórcio, a separação judicial e o restabelecimento da sociedade conjugal". Trata-se de requisito para a habilitação para novo casamento..$^{64}$ Segundo a jurisprudência brasileira, a interpretação destas normas pode ser no sentido que o divórcio consensual não necessita realizar a partilha (Súmula 197 do STJ), ${ }^{6.5}$ e que a renúncia da esposa aos alimentos é definitiva, ${ }^{66}$ sem que isto ofenda a nossa ordem pública.

No Direito Internacional Privado, o Art. 7 da LICC/42 dispõe: " A lei do país em que for domiciliada a pessoa determina as regras sobre o começo e ofim da personalidade, o nome, a capacidade e os direitos de família." O $₫ 6^{\circ}$ do Art. $7^{\circ}$ da LICC/42 refere-se à homologação de sentenças de divórcio de brasileiros, impondo os mesmos prazos da lei do divórcio de 1977. Seu espírito é positivo para a homologação destas sentenças:

\footnotetext{
${ }^{62}$ Assim o texto: "Art. 1.571. A sociedade conjugal termina: 1 - pela morte de um dos conjuges; II pela nulidade ou anulação do casamento; III - peła separação judicial; XV - pelo divórcio. $\$ 1^{\circ} O$ casamento válido só se dissolve pela morte de um dos cônjuges ou pelo divórcio, aplicando se a presunção estabelecida neste Código quanto ao ausente. $\$ 2^{\circ}$ Dissolvido o casamento pelo divórcio direto ou por conversão, o cônjuge poderá manter o nome de casado; salvo, no segundo caso, dispondo em contrário a sentença de separação judicial."

${ }^{63}$ Veja resumo do conteúdo destas normas dos Art. 1571 a 1582 in SENISE LISBOA, Roberto, Manual Elementar de Direito Civil, vol. 5 - Direito de Familia e Sucessōes. 2. ed., São Paulo:Ed. Revista dos Tribunais, 2002, p. 126-133.

${ }^{64}$ Assim o texto: "Art. 1.525. O requeximento de habilitação para o casamento será firmado por ambos os nubentes, de próprio punho, ou, a seu pedido, por procurador, e deve ser instruído com os seguintes documentos:...V - certidão de óbito do cônjuge falecido, de sentença declaratória de nulidade ou de anulaçâo de casamento, transitada em julgado, ou do registro da séntença de divórcio."

${ }^{65}$ Veja a Súmula 197 do Superior Tribunal de Justiça: "O divórcio direto pode ser concedido sem que haja prévia partilha de bens"

${ }^{66}$ Assim decisões do Superior Tribunal de Justiça, veja por exemplo Recurso Especial 85.683/SP: "Alimentos. Renúncia. Divórcio. É válida e eficaz a cláusula de renúncia a alimentos ("săo ficou estabelecida qualquer cláusula que obrigava o ex-marido a presta alimentos à ex - mulher", segundo o acótdão recorrido), em acordo de separação. Quem renuncia, renuncia para sempre. $O$ casamento válido se dissolve pelo divórcio. Dissolvido o casamento, desaparecem as obrigaçòes entre os cônjuges. A mútua assisténcia é própria do casanıento. llegitimidade de parte ativa da mulher para a ação. Recurso especial năo conhecido."(STJ, Ministro Nilson Naves, in RSTJ -.. nr. 90 - ano 9 - fevereiro de 1997)
} 
"Art. $7^{\circ} \ldots \$ 6^{\circ}$. O divórcio realizado no estrangeiro, se um ou ambos os cônjuges forem brasileiros, só será reconbecido no Brasil depois de três anos da data da sentença, salvo se bouver sido antecedida de separação judicial por igual prazo, caso em que a bomologação produzirá efeito imediato, obedecidas as condiçóes estabelecidas para a eficácia das sentenças estrangeiras no País. O Supremo Tribunal Federal, na forma de seu regimento interno, poderá reexaminar, a requerimento do interessado, decisões já proferidas em pedidos de bomologação de sentenças estrangeiras de divórcio de brasileiros, a fim de que passem a produzir todos os efeitos legais."'67

Não há unanimidade entre os autores brasileiros qual a lei indicada aplicável para o divórcio de estrangeiros no Brasil, se a do domicílio conjugal, segundo o Art. $7^{\circ}$ caput como lei geral para os direitos de familia, ${ }^{68}$ ou, como parte da doutrina defende, a lei da nacionalidade comum destes cônjuges, em interpretação do $\$ 6^{\circ}$ do Art. $7^{\circ}$ da LICC/42 como estabelecendo o elemento de conexão nacionalidade. ${ }^{69}$

\section{A EVOLUÇÃO HISTÓRICA DAS NORMAS SOBRE O DIVÓRCIO E A EXCEÇÃO DE ORDEM PÚBLICA EM MATÉRIA DE DIVÓRCIO}

Antes de passarmos ao exame das normas brasileiras que tegem o reconhecimento hoje das sentenças de divórcio, e o exame dos casos levantados, mister relembrar a evolução histórica da instituição divórcio no Brasil. Como antes mencionado até a Emenda Constitucional de 1977, as constituições hrasileiras consideravam o casamento indissolúvel, logo, a instituição 'divórcio' era desconhecida no país. ${ }^{70}$

\footnotetext{
${ }^{67} \mathrm{LICC} / 1942$ com redação dada pela Lei $n^{\circ} 6.515$, de 26.12.77.

th Assim opinião de VIlLELA, p. 24 e seg. e p. 66 e seg. a quen seguimos nesta opinião, uma vez que utiliza a separação judicial como parâmetro.

"Nesta linha de pensamento encontrava-se o grande Haroldo Valladão, veja revisão de toda a a literatura brasileira de DIPriv. da época, VILLEZA, p. 20 a 24.

${ }^{70}$ Assim VILLEL_A, p. 3, refexindo-se à Emenda Constitucional nr. 9, de 28 de junho de 1977 que pôs fiǹ à interdição do divórcio no Brasil.
} 
Como explica Oscar Tenótio, a justiça brasileira de 1894 a 1917 (data da entrada em vigor das normas da Introdução ao Código Civil) sempre considerou que "o divórcio é um ato jurídico perfeito, cujas conseqüências são admitidas em toda parte" " daí discutir-se se seu reconhecimento no Brasil ofendia ou não à ordem pública. Vejamos a evolução.

O Código Civil Brasileiro de 1916, que entrou em vigor em $1^{\circ}$ de janeiro de 1917 , como ensina Haroldo Valladão,adotara "em sua introdução, art. $8^{\circ}$, o princípio da lei nacional para os direitos de família e, art. 17, o limite da ordem pública. Daíperdurar a jurisprudência da inadimissibilidade da decretação de qualquer divórcio 'a vínculo' no Brasil, por ser contrário à ordem pública lacórdão leader do STF, Ap. Cív. 2755, Rev. Sup. Trib. Fed. 30/194)...A jurisprudência evoluiu com um espírito muito largo...A princípio, recusava simplesmente a bomologação às sentenças estrangeiras de divórcio, que eram todas consideradas contrárias à ordem pública; depois bomologou-as somente para efeitos patrimoniais... facilitando, assim, a vida no Brasil dos divorciados no estrangeiro (Clunet, 1932, 1.111 a 1.120). Foi um aplicação feliz do princípio da aproximação ou adaptação...Afinal, concedeu a bomologação, para todos os efeitos, inclusive os de contratar novo casamento no Brasil, se o divórcio era admitido pela lei do lugar onde foi promulgado e pela lei nacional dos cônjuges, o que exclui os brasileiros. Se um dos cônjuges era brasileiro $e$ o outro estrangeiro, reconhecia a sentença estrangeira para o brasileiro, com efeitos somente patrimoniais, e para o estrangeiro, se a lei nacional o autoriza-se, para todos os efeitos, inclusive o de novo casamento no Brasil, o que criava uma situação de desigualdade que chocava a opinião pública."

A nova Lei de Introdução de 1942 pôs fim às controvérsias estabelecendo claramente que o reconhecimento de sentenças de divórcios de estrangeiros, mesmo que domiciliados no país, era possível, mas seu novo casamento no Brasil , não. Assim afirmava expressamente o Art. $7^{2}, \$ 6^{\circ} \mathrm{da}$ Lei de Introdução ao Código Civil até 1977 :

"Art. 7,\$6". Não será reconbecido no Brasilo divórcio, se os cônjuges forem brasileiros.

Se um dêles o fôr, será reconbecido o divórcio quanto ao outro, que não poderá, entretanto, casar-se no Brasil."

Em resumo, antes de $1917,^{72}$ mesmo para reconhecimento e para verificar se havia fraude à lei, o elemento de conexão indireto utilizado era o da nacionalidade de cada cônjuge, a "lei da sua pátria"." Depois de 1942, o elemento de conexão principal passou a ser o domicílio, mas a Lei de Introdução de 1942 rompia seu próprio sistema em matéria de

\footnotetext{
71 TENÓRIO, P. 287 (n. 544).

72 Sobre o direito brasileiro durante o Império, muito baseado na religião de cada pessoa, veja VALLADÃO, Mi, p. 124 (nr. 11).

${ }^{73}$ Assim TENÓROO, p. 288 (nr. 547)
} 
divórcio e, mesmo assumindo como elemento de conexão principal, do Art. $7^{\circ}$ caput, o domicílio da pessoa, manteve en matéria de divórcio uma autorização especial de reconhecimento de sentenças estrangeiras de divórcio de pessoas domiciliadas no Brasil, se estrangeiras e se sua lei nacional (e a do foro) permitia o divórcio! $!^{74}$

Como ensina Ana Maria Villela, em matéria de reconhecimento de sentenças, a matéria foi desenvolvida mais pelos juízes do que pela legislação, e o exame concentrava-se na competência do juiz estrangeiro que ditava o divótcio, esta sim dada pela nacionalidade dos cônjuges ou seu domicílio. Sendo assim, a justiça brasileira reconhecia os atos de divórcio de estrangeitos, em foros competentes e se sua lei assim permitisse este divórcio. ${ }^{75}$

Interessante notar que os textos dos Art. 52 e 56 do Código de Bustamante que previam o elemento de conexão do domicílio matrimonial para o divórcio e a separação nunca entraram em vigor no Brasil. ${ }^{76} \mathrm{O}$ Art. 318 deste Código permitia que os cônjuges submetem-se, nestas ações a competência de um foro escolhido, o que segundo Valladão, ${ }^{77}$ também não foi aceito no Brasil em matéria de divórcio, como demonstrou a posterior jutisprudência do STF na Súmula $381 .^{78}$

A Súmula 381 do Supremo 'Tribunal Federal veio justamente combater este tipo de 'fraude à lei', pois os estrangeitos domiciliados no Brasil passaram a utilizarse de foros facilitários do divótcio, como o México ou Reno (Estados Unidos da América ), e a divotciarem-se por procuração, em países que não eram nacionais ou com os quais não tinham em princípio nenhuma conexão verdadeira. Estes divórcios não foram reconhecidos pelo STF, apesar dos cônjuges terem ambos 'escolhido' voluntariamente estes foros. ${ }^{79}$

\footnotetext{
${ }^{74}$ Assim TENÓRIO, p. 291 (nr. 544), relembrando que este exa o critério da Convenção de Haia de 12 de junho de 1902, para regular os conflitos de less e jurisdições, em matéria de divórcio e separação de corpos, assim também SAMPAIO, p. 106

${ }^{75}$ VHLLEL $\Lambda$, P. 8 a 11 , examinando todos os primeiros casos do STF.

${ }^{76}$ Assim VALLAD $\tilde{\Lambda} O$, t. III, p. 122 (nr. 10). O Código Bustamante de 1928 dispunha: "Artigo 52.0 direito à separação de corpos e ao divórcio regula-se pela lei do domicilio conjugal, mas não se pode fundar em causas anteriores à aquișição do dito domicilio se as näo autorizar, com iguais efeitos, a lei pessoal de ambos os cônjuges."

"Assim VALLAD $\tilde{O}$, t. Mr, p. 122 (nx. 10).

78 SAMPAIO, p. 23.

7) Veja sobre os casos que levaram a elaboraçâo da Súmula, SAMPAIO, p. 21 a 24.
} 
A Súmula 381 do $\mathrm{STF}_{9}^{80}$ consolida a jurisprudência brasileira no sentido de que:

"Não se bomologa sentença de divórcio obtida por procuraf̧ão, em país de que os cônjuges não eram nacionais".

Note-se que a circunstância dos estrangeiros serem casados no Brasil ou manterem aqui seu domićlio nunca foi considerada impeditiva do divórcio no exterior e de seu reconhecimento pelo STF ${ }^{81}$ Da mesma forma, o direito brasileiro sempre foi bastante estrito, seja considerando as mudanças automáticas de nacionalidade como fraude à lei, seja não concedendo a nacionalidade brasileira à mulher que casasse com nacional, sendo assim podia esta obter o divórcio como estrangeita no exterior. ${ }^{82}$

Vejamos a base legal atual sobre ofensa à ordem pública. Segundo ensina Jacob Dolinger, a exceção de ordem pública não é passivel de definição, sendo relativa, casuística e contemporânea: "A Ordem Pública no DIPR impede a aplicação de leis estrangeiras, o reconbecimento de atos realizados no exterior e a execução de sentenças proferidas por tribunais de outros países, constituindo-se no mais importante dos princípios da disciplina. ${ }^{1 * 3}$ A determinação se um ato estrangeiro ou uma decisão ou sentença de divórcio ofende a ordem pública brasileira é feita pelo juiz, no caso concreto e com as noções do dias de hoje. Concordese com Andreas Bucher que a função primeira da cláusula de exceção da ordem pública é preservar os valores essenciais de justiça da ordem jurídica do foro. ${ }^{84}$

A base legal da exceção de ordem pública atual ainda é o Art. 17 da Lei de Introdução ao Código Civil de 1942, que dispõe:

"Ant. 17. As leis, atose sentenças de outro país, bem como quaisquer decla araçẽes de vontade, não terão eficácia no Brasil, quando ofenderem a soberania nacional, a ordem pública e os bons costumes."

Também a Convenção Interamericana sobre Normas Gerais de Direito Internacional Privado - que não é aplicada em relação a casos japoneses, mas pode servir de inspitação ao juiz brasileiro - próbe a fraude à lei nos seguintes termos: ${ }^{85}$

\footnotetext{
${ }^{B 0}$ Veja SAMPAIO, p. 23.

"Asim ensina SAMPAIO, p. 27.

*2 Veja o exame das várias hipóteses de fraude à le na mudança de nacionalidade e o problema da nacionalidade da mulher casada com brasileiro, in SAMPAIO, p. 29 a 39.

${ }^{83}$ DOLINGER, Jacob, A evolução da Ordem Pública no Direito Internacional Privado, Rio de Janeiro, 1979, p. 329) e 330. Veja também CALIXTO, Negi, Ordem Pública, Curitiba, Editora Universidade Federal do Paraná, 1987.

${ }^{84}$ Assim BUCHER, Andreas, L'ordre public et le but social des lois em Droit International Privé, Recueil de Cours, tomo 239,1993, p. 69.

".5 En vigor no Brasil através do Decreto $n^{\circ} 1.979$, de 9 de agosto de 1996.
} 
ODireito Internacional Privado solucionando 'conflitos de cultura':

"Artigo 6. Não se aplicará como direito estrangeiro o direito de um Estado Parte quando artificiosamente se tenbam burlado os princípios fundamentais da lei do outro Estado Parte.

Ficará a juizo das autoridades competentes do Estado receptor determinar a intenção fraudulenta das partes interessadas."

Quanto ao reconhecimento de sentenças a base legal expressamente inclui a exceção da ordem pública no Art. 15 da LICC/42:

“Art. 15. Será executada no Brasil a sentença proferida no estrangeiro, que reúna os seguintes requisitos:

a) baver sido proferida por juiz competente;

b) terem sido as partes citadas ou baver-se legalmente verificado a revelia;

c) ter passado em julgado e estar revestida das formalidades necessárias para a execução no lugar em que foi proferida;

d) estar traduzida por intérprete autorizado;

e) ter sido bomologada pelo Supremo Tribunal Federal.

Parágrafo único. Não dependem de bomologação as sentenças meramente declaratórias do estado das pessoas."

Este artigo foi modificado pelos Artigos 483 do CPC e 216 e 217 do Regimento interno do Suptemo Tribunal Federal, como veremos. ${ }^{86}$ Os requisitos formais necessátios para o Supremo Tribunal Federal conceder uma homologação, são, segundo os artigos $216 \mathrm{e}$ 217 do Regimento Interno do STF, os seguintes: competência do juiz prolator; terem sido as partes citadas ou haver-se legalmente verificado a revelia, ter passado em julgado e estar revestida das formalidades necessátias à execução no lugar em que foi proferida, estar autenticada pelo cônsul brasileiro e acompanhada de tradução oficial, além do requisito da negativa de ofensa à soberania nacional, à ordem pública e aos bons costumes. ${ }^{87}$

\footnotetext{
86 Veja também Art. 483 do C.P.C. e R.I.S.T.F., art. 217, II ( terem sido as partes citadas ou haverse legalmente verificado a revelia), III (ter passado em julgado e estar revestida das formalidades necessáxias à execução no lugar en que foi proferida) e IV (estar autenticada pelo cônsul brasileiro e acompanhada de tradução oftcial), além do requisito da negativa de ofensa à soberania nacional, à ordem pública e aos bons costumes (art. 216 do R.I.S.T.F). Veja também o artigo 15 da LICC.

${ }^{87}$ BARBOSA MORETM $\Lambda$, José Carlos. Comentários ao Código de Processo Civil : Vol. 5 (Arts. 476 a 565 ), Rio de Janeiro: Forense, 1998, p. 59.60.
} 
Antes de passarmos ao exame dos 30 casos aqui estudados, mister observar que, como ensina Pedro Sampaio, o direito brasileiro desde a Sentença Estrangeira nt. 912 da Dinamarca sempre reconheceu o divórcio emanado de autoridade administrativa: " $A s$ sentenças de divórcio pronunciadas por autoridade administrativa do poder executivo, consoante os ditames internos do Estado do qual emanam, 'preenchem, no particular, o exigido por nossa lei, podendo, tais decisóes, ser homologadas, independentemente do grau bierárquico de quem as proferiu.

Ao contrário, em matéria de autoridade religiosa, o divórcio realizado de pessoas domiciliadas no Brasil, normalmente não era reconhecido pelo STF, por falta de competência desta jurisdição, como demonstra a Sentença Esrrangeira nt. 2016 do Lỉbano, cuja ementa ensina:

"As relaçôes de família não se submetem, no território brasileiro, a outra jurisdição que não a dos tribunais civis, instruidos por lei.

\section{II - O RECONHECIMENTO DOS DIVÓRCIOS CONSENSUAIS JAPONESES PELOSUPREMO TRIBUNAL FEDERAL}

Segundo demonstrou nosso levantamento dos 30 casos de divórcios japoneses reconhecidos pelo STF desde a entrada em vigor da Constituição de 1988 até agosto de 2002, o STF não demonstra qualquer dificuldade em reconhecer estes divórcios privados e afirma:

“Écertoprezero artigo 102, inciso I, alinea b', da Constituição Federal a competência do Supremo Tribunal Federal para processar ejulgar, oniginalmente, a bomologação de sentencas estrangeiras todavia, háde adotar-se interpretação aditizx, vidumbrandose, na veferência asentensasestrangeiras, documentosque, segrindo a legidação daorigem, tenham tal envergadura Éocasodoato administrativo dedivóncio. NoJapão, odexenlacematrimonial nãoéalcançadovia sentenç, mas modianteo registro nocartónio competente, atuando oadministrador do distrito." ${ }^{. \times 1}$

Efetivamente, a Constituição Federal no seu arr.102, inciso I, alínea "h" estabelece a competência do STF para processar e julgar a homologação de sentenças estrangeiras e, segundo esta interpretação majoritária, estaria inserido nesse conceito, qualquer documento que segundo a legislação da origem do país se tenha como

\footnotetext{
SAMPAIO, p. 73.

8. SAMPAIO, p. 76 .

\$ Assim decisão na SE 7039/JA, Min. Marco Aurélio, j. 20.03.2002, MARQUES/JACQUES/ SCHMIDT, p. 185.
} 
funcionalmente válido para decretar o divórcio. ${ }^{91}$ Efetivamente, mesmo antes da introduçâo do divórcio no Brasil, em 1977, o STF reconhecia divórcios proferidos no exterior de estrangeitos, afirmando: "Homologa-se o divórcio se foi feito com as formalidades de seu pais de origem." (STF, SE 1382-Noruega). ${ }^{92}$

Vejamos o processo de delibação brasileiro sobre o tema (A) e o exame dos casos concretos (B).

\section{A-O PROCESSO DE DELIBAÇÃO ADAPTADO AOS DIVÓRCIOS PRIVADOS JAPONESES}

O reconhecimento das decisões estrangeiras é uma parte importante do Direito Internacional Privado ou do Processo civil Internacional, visando justamente garantir o atendimento das finalidades de harmonia internacional de decisões almejada por estas disciplinas. Visa igualmente dar às partes a segurança jurídica através da circulação dos julgados e atos, o reconhecimento dos direitos adquiridos e situações juridicamente constituídas no exterior. Como ensina o grande mestre português, também recentemente falecido, Antonio Marques dos Santos: "o fundamento do recombecimento das senten sas estrangeiras éa continuidade das situaçõesjurídico-privadas internacionais, a sua previsibilidade, a seguransa juridica que deriza da atuação consoantè̀ expectatizas fundadas dos sujeitos de direitos: trata-se pois de justiça formal, própria do Direito Internacional Privado..." ${ }^{193}$

\section{A DELIBAÇÃO CONCENTRADA NO SUPREMO TRIBUNAL FEDERAL}

Desde 1894, o reconhecimento de sentenças estrangeiras está concentrado no Supremo Tribunal Federal, ${ }^{, 4}$ mas as sentenças civeis meramente declaratórias não

\footnotetext{
ir Assim RECHSTINER, p. 199.

${ }^{22}$ SAMPAIO, p. 97.

${ }^{93}$ MARQUES DOS SANTOS, Antonio. Estudos de Direito Internacional Privado e de Direito Processual Civil Internacional, Coimbra, Almedina, 1998, p.309.

${ }^{4}$ Veja BOUCAULT, Carlos Eduardo de $\Lambda$ breu, Homologação de sentença estrangeira e seus efeitos perante o STF, Ed. Juarez Freitas, São Paulo, 1999, p. 5.
} 
necessitavam de exequatur no Brasil. ${ }^{95}$ Certo é que as decisões (privadas, administrativas ou judiciais) necessitam de homologação pelo Supremo Tribunal Federal, no sistema do direito brasileiro atual, não podendo ser averbadas diretamente. Segundo a posição majoritária da doutrina o parágra fo único do Art. 15 da Lei de Introdução ao Código Civil de 1942 (que a firma: "Não dependem de bomologação as sentenças meramente declaratórias do estado das pessoas"), foi derrogado pelo Art. 483 da lei mais nova especial, o Código de Processo Civil, impondo-se hoje a necessidade de homologação de qualquer sentença estrangeira, inclusive a de divórcio, as decisões arbitrais e as proferidas em jurisdição voluntária. $O$ art. 483 do Código de Processo Civil dispõe que: "A sentença proferida por Tribunal Estrangeiro não terá eficácia no Brasil se não depois de homologada pelo Supremo Tribunal Federal." Neste sentido decidiu definitivamente o Supremo Tribunal Federal na Petição avulsa nr. 11:

"Sentença estrangeira de divórcio. Pedido de averbação desse ato sentencial dirigido a magistrado estadual. Alegada desnecessidade de prévia bomologação, em face do art. 15, parágrafo único da LICC. Norma legal derrogada pelo CPC (art. 483). Magistério da doutrina. Impossibilidade processual da instauração de delibação incidente. A̧̧ão de bomologação de sentença estrangeira. Sistema de contenciosidade limitada. Evolusaão do instituto no direito brasileiro. Indispensabilidade da homologação prévia de qualquer sentença estrangeira, quaisquer que sejam os efeitos postulados pela parte interessada. Precedente do STF."

Como ensina Rechsteiner, ${ }^{1 / 6}$ mesmo realizadas frente a um órgão administrativo as decisões de divórcio estrangeiras por mútuo consentimento podem set reconhecidas no Brasil, se "em conformidade com o sistema jurídico do país de origem". A doutrina brasileira sempre foi bastante positiva e flexivel em relação a decisões administrativas, arbitrais e mesmo religiosas, afirmando Pontes de Miranda: " $N$ a expressão sentenças estrangeiras compreendem. se todas as decisões judiciais que precisam ter eficácia alhures desde que decisão cível ou com eficácia cível. Incluem-se as decisóes arbitrais $e$ as autoridades administrativas, se tem eficácia cível." "97

\footnotetext{
${ }^{5}$ Assim ensina, en seu livro de 1906, o autor do Código Civil Brasileiro de 1916, BEVILAQUA, Clóvis, Princípios elementares de Direito Internacional Privado, Edição histórica da obra de 1906, Ed. Rio: Rio de Janeiro, 1988, p. 326. Veja-se decisão do Tribunal de Justiça do Rio de Janeiro, de 22 de maio de 1953, em que se afirmava: "A sentença estrangeira de divórcio não depende de homologação quando metamente declaratória do estado da pessoa." (in TENORIO, Oscar, Lei de Introdução ao Código Civil Brasileiro, Ed. Borsoi: Rio de Janeiro, 1955, p. 434, nota 4.

${ }^{96}$ RECHESTEINER, Beat Walter. Direito Internacional Privado, São Paulo: Saraiva, 1996, p.202.

"27 PONTES DE MIRANDA, Francisco Cavalcanti. Comentários ao Código de Processo Civil, Tomo VI,Rio de Janeiro, Ed. Forense, 1974, p.90.
} 
O sistema seguido pelo direito brasileito é o da delibação. ${ }^{98}$ Seguindo o modelo italiano antigo, realiza o STF somente um juízo de delibação sem avaliar, no entanto, o mérito da decisão estrangeira a ser homologada. ${ }^{99}$ Esse juízo de delibação visa assegurat que a decisão estrangeira preencheu os requisitos de homologabilidade exigidos pela legislação brasileira não existindo ofensa à ordem pública, à soberania nacional ou aos bons costumes, mas aqui o exame é limitado. ${ }^{10(\lambda)}$ Efetivamente, o STF tem reiteradamente negado alargar as discussões no processo delibatório ${ }^{\text {101 }}$ e utiliza-se de uma noção de ordem pública bastante restrira. ${ }^{102}$

Os requisitos formais necessários para o Supremo Tribunal Federal conceder uma homologação, são, segundo os artigos 216 e 217 do Regimento Interno do STF, os seguintes: a) competência do juiz prolator; b) citação do réu; c) trânsito em julgado do ato sentencial; $\mathrm{e}$ d) autenticidade e tradução por tradutor juramentado. ${ }^{103} \mathrm{Os}$ demais tequisitos encontram-

\footnotetext{
${ }^{98}$ Assim BOUCAULT, Carjos Eduardo de Abreu, Homologação de sentença estrangeira e seus efeitos perante $O$ $S T F$, Ed. Juater Freitas, Săo Paulo, 1999, que afima na p. 15: "O sistema jurídico vigente no Brasil sobre homologação de sentença estraneira vincula-se ao princípio da Delibação, procedente do sistema italiano e consagrado pelos internacionalistras tranceses. O procedimento da delibação atribui competência para o tribunal examinar os aspectos formais da sentença, sem contudo, pronunciarse sobre o mérito do julgado, ou do direito material objeto do direito estrangeiro confrgurado nos limites da sentença."

"Assim DOLINGER, Jacob. Brazilian Confirmation of Foreign Judgments, in International Lazeryer, 1985, Vol. 19, Number 3, p. 854.

Meja Sentença Estrangeira Contestada no 5093. Origem: EUA. Publicação: DJ 13/12/1996, Votação Unânime,Deferido, Min. Celso de Mello: "Ementa: ...A Homologação pelo S.T.F. constitui pressuposto de eficácia das sentenças proferidas por tribunais estrangeiros. - As sentenças proferidas por tribunais estrangeiros somente terão eficácia no Brasil depois de homologadas pelo Supremo Tribunal Federal. O processo de homologação desempenha, perante o Suptemo Tribunal Federal que é o Tribunal do foro ", uma função essencial na outotga de eficácia às sentenças emanadas de Estados estrangeiros. Esse processo homologatório - que se reveste de caráter constitutivo - faz instaurar, pexante o Suptemo Tribunal Federal, uma situação de contenciosidade limitada. Destinàse a ensejar a verificação de determinados requisitos fixados pelo ordenamento positivo nacional, propiciando, desse modo, o reconhecimento, pelo Estado brasileiro, de sentenças estrangeiras, com o objetivo de viabilizar a produção dos efeitos jurídicos que lhes são inerentes..."

101 Veja Sentença Estrangeira Contestada no 4795- Suiça, Dj 20/10/1995,j. 16/08/1995, Min. Mautício Cotrea: "Ementa: Sentença Estrangeira Contestada. Divórcio. Homologação. $O$ art. 221 do Regimento Interno do Supremo Tribunal Federal delimita o campo para que se estabeleça eventual contraditório, não sendo possivel, pela via processual de sentença estrangeira, discutir situações jurídicas diversas dos requisitos indispensáveis a homologação. Preenchidos os requisitos regimentais, defere-se o pedido de homologação da sentença estrangeira."

iuz Veja-se controvérsia sobre os limites do sistema da delibaçäo e a prosição restritiva do STR, Sentença Estrangeira n 5.179-7-Portugal e Sentença Estrangeira n. 4.321-1-França, ambas comentadas por BOUCAUL, p. 41 e 42.

${ }^{103}$ BARBOSA MORETRA, José Catlos. Comentários ao Código de Processo Civil: Vol. 5 (Arts. 476 a 565), Rio de Janeiro: Forense, 1998 , p. 59-60.
} 
se repetidos no Art. 15 da LICC/42 e Art. 483 do CPC e são todos voltados para sentenças ou decisões de instâncias públicas.

O mestre português Álvaro da Costa Machado Villela, elogiava o direito brasileiro afirmando: "O único sistema lógico éo sistema da delibação, en quanto reconbece a decisão do tribunal estrangeiro e limita os poderes do tribunal do exequatur a um exame formal, para verificar se trata-se de uma sentença regular e definitiva, revestida de autenticidade, proferida por tribunal competente não contrária às leis locais de interesse e ordem pública. Com efeito, em face do respeito devido às jurisdições internacionalmente competentes para decidir as questôes entre particulares, o tribunal do exequatur não deve apreciar o mérito da decisão."

Interessante destacar que este autor português preocupou-se com a análise dos efeitos que podem ter a decisão estrangeira, mesmo declaratótia de divórcio, a ser homologada e ensina: "Sob dois aspectos gerais uma sentença estrangeira pode ser invocada: ou como ato de jurisdição que declarou um direito de modo definitivo; ou como um simples documento donde consta a verificação de um fato ou de um direito". E continua: "quando a sentença estrangeira é invocada como ato de jurisdição, ainda o pode ser para um de dois fins: ou para servir de título executivo numa execução forçada; ou para produzir qualquer outro efeito inerente ao caso julgado, como para fazer um registro predial ou para deduzir a exceção de caso julgado."165 Aqui uma observação importante, pois o efeito da homologação da declatação registrada de divórcio no Japão é apenas declaratótio no território brasileiro, a indicar que realmente a visão positiva do direito brasileiro em relação às diferenças culturais Brasil-Japão, pode indicar um caminho certo: hatmonia internacional de decisões e respeito às diferenças culturais!

\section{A ORDEM PÚBLICA BRASILEIRA EM MATÉRIA DE DIVÓRCIOS}

Analisando a ordem pública em maréria de homologação de sentenças, Boucault defende que o: "conceito de ordem pública, dada sua amplitude e lasticidade, deve comportar um abrandamento na aplicasão da noma estrangeira, em observância à liberdadecultural dos ponos". $11 \%$ Como ensina Rechsteiner, são taros os casos em que o Supremo Tribunal Federal considera a ordem pública brasileira violada em virtude de motivos de direito material, geralmente são os requisitos processuais antes expostos os mais usados. ${ }^{107}$

\footnotetext{
${ }^{104}$ MACHADO VILLELA, Alvaro da Costa, O Direito Internacional Privado no Código Civil Brasileiro, Coimbra, Imprensa da Universidade, 1921, p. 505.

t.05 MACHADO VILLELA, P. 505.

:166 BOUCAULT, p. 47.

ti) RECHSTEINER, p. 205.
} 
As críticas de Yuko Nishitani, quanto a não equivalência funcional dos divórcios privados japoneses às sentenças e de possíveis violações a nossa ordem pública devem sex aqui examinadas. O primeiro aspecto levantado é o fato dos divórcios japoneses geralmente não envolverem a partilha dos bens do casal. Aqui vários poden ser os comentários. No leading case da Sentença Estrangeira n. 4.512-6-Confederação Helvética, ${ }^{108}$ em que casal de brasileiros, residentes na Suíça requeriam a homologação de sentença de divórcio consensual sem partilha, esta homologação foi concedida, urna vez que a partilha tinha se rcalizado anos antes, na separaçăo. ${ }^{109}$ Note-se que a competência para realizar partilha de bens situados no Brasil, por força do Art. 89, I e 89, II do CPC é exclusiva do juiz brasileiro. ${ }^{110}$ Também conhece o direito brasileiro o divórcio sem partilha de hens (que será realizada no futuro ou já realizou-se no passado). Assim dispõe também a Súmula 197 do Superiot Tribunal de Justiça: "O divórcio direto pode ser concedido sem que haja prévia partilha de bens". $\mathrm{Na}$ Sentença estrangeira 4844, o Ministro Gallotti deferiu uma homologação com ressalvas, excluindo a partilha dos bens situados no Brasil, pois estes de exclusiva competência do juiz brasileiro. ${ }^{111}$ Sendo assim, conclui-se que -frente ao STF- é até mais fácil realizar-se a homologação de uma decisão estrangeira de divórcio consensual japonês se esta não regular a partilha de bens!

O segundo aspecto é a necessária proteção do cônjuge mulher. Quanto à competência, bastante controvérsia é a vigência do Art. 100, I do CPC de um foro prjvilegiado para a mulher em matéria de divórcio, após a entrada em vigor da Constituição Federal de 1988 e seu Art. $5^{\circ}$ sobre isonomia entre homens e mulheres. ${ }^{112}$ Em outras palavras, a rradição da jurisprudência brasileira é considerar este foro privilegiado como competência concorrente e interprerar a norma mesmo restritivamente,

\footnotetext{
lub SE 4.512-6, julgada em 21 de outubro de 1994 pelo STF.Veja comentários sobre o caso de BOUCAULT, p. 39 a e seg.

109 Assim BOUCAULT, p. 40.

110 Veja sobre o tema e antecedentes desta norma, DOLINGER, Jacob, Sentença estrangeira de divórcio, in Revista Forense, vol. 297, p. 207.

11 SE 4844, i. 04.10.1993, comentada por NERY, Nelson Júnior e NERY,Rosa Maria de Andrade Nery, Código de Processo Civil Comentado, 6.ed., Editora Revista dos Tribunais, São Paulo, 2002,p. 794.

112 Veja CAMBI, Eduardo, Foro privileryiado da mulher, isonomia constitucional na sociedade conjugal e processo civil, in Revista de Processo nr. 83, p. 186 e seg.
} 
pata determinar a própria incompetência da justiça brasileira caso apenas o marido aqui seja domiciliado, isto como forma de 'proteger' as esposas. ${ }^{113}$ Em resumo, a doutrina e a jurisprudência brasileiras são unânimes ao reconhecer e interpretar o art. 100, inciso I do CPC como assegurando competência do juízo da residência da mulher brasileira, se esta for a autora ou a ré da ação de divórcio. ${ }^{114}$ Trata-se, porém, de competência relativa, sendo assim poderia ser alterada (prorrogada) por vontade de ambas as partes, como o foi no caso dos divórcios consensuais japoneses. Esta linha da jurisprudência poderia, porém, ajudar a esposa residente no Brasil, caso o divórcio japonês tenha sido realizado sem ou contra sua vontade. ${ }^{115}$ Jacob Dolinger defende veementemente a aplicação, em casos atípicos ou internacionais do art. 100, inciso I do CPC, considerando-a importante questão de Justiça para a proteção da esposa estrangeira residente no Brasil ou em ourro país: "A tese defendida pela mulher de que lhe cabia o privilégio do foro com base no artigo 100,I, do CPC não poderia ter sido negada, com o argumento que vários tribunais invocam de que seu domicílio era efetivamente no Brasil por força do domicílio local do marido." "16 Igualmente, defende a aplicação do Art. 100, I do CPC sempre a favor da esposa, Ana Maria Villela. ${ }^{117}$

13 Exemplo desta linha é a decisão do TJ/RS, assim ementada: “Competência. Ação de divórcio. Casal estrangeiro. Sepaxação de fato há mais de cinco anos. Incompetência da justiça brasileira. Esposa năo residente no Brasil. Carência decretada. É incompetente a justiça brasileira para julgar pedido de divórcio de casal estrangeiro cujo casamento nảo se realizou no Brasil e aqui nunca residiu a esposa, contra quem é movida ação "(Ap. Civ. 21.907, 2.Cciv. in RT 572/ 55 e Lex 81, p. 54.) Veja também as decisóes do TJ/ES: "Competência. Divórcio. Casamento celebrado no estrangeiro, de casal também estrangeiro. Residência dele no Brasil e dela no exterior. Carência de ação. Incompetencia da justiça brasileira pata processar a ação." (Ap. civ. 48.247-1, in Lex 91-RJTJWSP, p. 66) e "Competência. Divórcio. Casamento realizado no estrangeiro. Réu não domiciliado no Brasil. Incompetência da Justiça brasileira para processar a ação. Sentença confirmada." (Ap. Civ. 14.142-1, in Lex 75-RJTJESP, p. 53.) Destaque-se a sempre respeitadissima opinião em contrátio de Yussef Said Cahali que defende a competencia sempre do juiz brasileiro para toda e qualquer causa de separação e divórcio, não importando as circunstâncias do caso, como forma de evitar a denegaçâo de justiça. Veja CAHALI, Yussef Said, Divórcio e Separação, Ed. RT, São Paulo, 1994, p. 597.

${ }^{114}$ Veja por todos, com extensa revisão da doutrina e jurisprudéncia, RIZZARDO, Arnaldo, Separação e Divórcio, in Direito de Família Contemporâneo, Coordenador Rourigo da Cunha Pereira, Del Rey, Belo Horizonte, 1997, p. 495 e seg.

13. Veja uecisão in RSTJ $3 / 341$ e decisão do STJ publicada in RT $657 / 184$ com a seguinte ementa: "Divórcio. Conversão da separação judicial. Competência. O pedido de conversão de separação em divớrcio deve ser formulado, em princípio, no foro do domicílio da mulher, e não, necessariamente, no juizo cm que se processou a separação. Desconhecido esse domicilio, o interessado poderá apresentálo no seu próprio, expondo-se a eventual exceção de incompetência por parte da mulhe. (Conflito de Competência nr. 704-RS, $2^{\circ}$ Seção do STj, i. 29.1.89).

${ }^{116}$ DOLINGER, p. 260.

${ }^{117}$ VILLELA, p. 60,62 e seg. 
De outro lado, como vimos, segundo o STF o simples fato do divórcio ser realizado frente a um órgão administrativo (por mediação estatal, por exemplo), frente a um tribunal religioso ou um árbitro/mediador, não ofende a ordem púbilca brasileira. Ao contrário, parece haver após 1977, uma espíriro brasileiro de 'favor divórcio' em nossa ordem pública. ${ }^{118}$ A pergunta é se o divórcio 'amigável' ou consensual apenas registrado pelo Prefeito municipal, como no Japão, ofende a nossa ordem pública. Pedro Sampaio em sua obra de 1973, portanto, anterior à introdução do divórcio no Brasil, já afirmava que não: "Homologa-se o divórcio amigável registrado no Japão pelo Prefeito municipal. A lei deste país reconhece como legal o divórcio consensual processado nessas condições". ${ }^{119}$

A tradição do STF,pois, é em sentido oposto, bastante flexível. de ourro lado, sempre mostrou-se aberto a reconhecer divórcios não-judiciais, desde que de acordo com a cultura local, seja quando estivesse presente alguma autoridade administrativa registradora ${ }^{120}$ ou mesmo religiosa. ${ }^{121}$

\section{B- EXAME DS 30 CASOS DE DIVÓRCIOS ‘JAPONESES’ NO STF DE 1975 A AGOSTO DE 2002}

Dos trinta casos examinados, 20 eram de divórcios por mútuo consentimento, registrado perante autoridade administrativa no Japão, 5 eram de divórcios 'judiciais' ou mediados e 5 eram de cartas rogatórias de citação em divórcios judiciais, um inclusive correndo frente à justiça brasileira. Vejamos os detalhes desres 29 'divórcios' ocorrendo no Japão e um divórcio judicial processado no Brasil.

\section{O EXAME DOS 20 CASOS DE DIVÓRCIOS CONSENSUAIS 'ADMINISTRATIVOS'}

A decisão do STF em 19 destes casos foi pelo deferimento do pedido de homologação. Na SE 4269, julgada em 16.08.1991, pelo Tribunal Pleno, o pedido não foi indeferido, mas sim o processo extinto (de forma a permitir novo pedido) face à instrução deficitária, pois não constava o original do registro administrativo japonês. A ementa da decisão foi a seguinte:

\footnotetext{
118 Veja neste sentido, sobre a 'inconstitucionalidade' de certos limites ao divórcio, ORESI DA COSTA, Carlos Celso, Tratado do Casamento e do Divórcio, 2.vol., Sào Paulo, Saraiva, 1987, p. 977 e seg. "17. SAMPA1O, P. 97, citando STF, SE 1312-Japão.

${ }^{120}$ Assim BASSO TAMAGNO, p. 86 e 87, cita o reconhecinento de decisão de divórcio decretado por autoridade administrativa da Noruega, Sentença Estrangeira n. 3.168, Noruega ${ }^{20.05 .1983, ~ R e t . ~}$ Min. Cordeiro Guetra.

121 Assim BASSO TAMAGNO, p.87 e 89, cita o reconhecimento de decisão de divórcio decretado por rabino em Israel, Sentença Estrangeira n. 3.584, Istael, 15.08.1985, Rel. Min. Moreira Alves.
} 
"Divórcio amigável, procedente do Japão. Ausência do teor do ato administrativo que se pretende bomologar, não bastando, para a bomologação, perante o STF, a prova da sua averbação, no registro civil (art. 218 e 219 e seu parágrafo único do regimento interno). Extinção do processo com ressalva da possibilidade de renovação do pedido, instruído com o documento indispensável." 122

Destes 19 deferimentos, 17 deram-se por decisão monocrática e 2 por decisão do Tribunal Pleno. Apenas nos dois casos da SE 2251/JA e da SE 6399/JA, a decisão foi do Tribunal Pleno. Nestes casos, é utilizada a expressão 'sentença estrangeira' para o ato administrativo japonês, utilizando-se o STF geralmente da seguinte ementa, que cita precedentes de homologação de divórcios 'privados' ou 'administrativos da Noruega, Dinamarca e Japão para conceder o pedido:

“SENTENÇA ESTRANGEIRA - HOMOLOGAÇÃO - DIVÓRCIO - ATO ADMINISTRATTVO EXTENSÃO. A norma inserta na alíned "b" do inciso I do artigo 102 da Constituicão Federal, segundo a qual compete ao Supremo Tribunal Federal processare julgar, originariamente, a bomologacão das sentençasestrangeiras, hádeser tomada respeitando-se asoberania do paisem quepraticadooato. Prevendo arespectiva legislação odivónio mediantesimples ato administratizo, como ocome, porexemplo, no Japão, cabivel é a bomologasão para que surta efeitos no territónio brasileiro. Precedentes: Sentenşa Estrangeira n ${ }^{\circ} 1.282 /$ Noruega, Relator $^{2}$ Ministro Mário Guimarães; Sentenca Estrangeiran ${ }^{\circ} 1.312$ /Japão, Relator Ministro Mário Guimarães; Sentenfa Estrangeira ${ }^{\circ}$ 1.943/Dinamarca, Relator Ministro Adaucto Cardoso; Sentença Estrangeiran ${ }^{\circ} 2.251$ / Japão, Relator Ministro Moreira Alves; Sentença Estrangeiran ${ }^{\circ}$ 2.626/Bélgica, Presidente Ministro Antonio Neder; Sentença Estrangeira n ${ }^{\circ} 2.891$ /Japão, Presidente Ministro Xavier de Albuquerque; Sentenças Estrangeiras n ${ }^{\circ}$ 3.298, 3.371 e3.372, todas do Japão, Presidente Ministro Cordeiro Guerra; e Sentença Estrangeira n ${ }^{\circ} 3.724$ / Japão, Presidente Ministro Moreira Alves. "(SEC 6399 / JA - Japão, Min. Marco Aurélio ,j. $21 / 06 / 2000)$

Nos outros 17 casos, ${ }^{123}$ a decisão monocrática do Presidente foi das mais simples e consta a seguinte ementa: "Certidão Adminsitrativa de Divórcio- Eficácia de SentençaHomologação". 124

122 Publicado in RTJ 137,02, p. 618 e in MARQUES/JACQUES/SCHMIDT, p. 214 e 215.

123 SE 3549/JA, SE 3869/JA, SE 5125/JA, SE 6527/JA, SE6607/JA, SE 6848/JA, SE 6878/JA, SE 6882/ JA, SE 7005/JA, SE 7039/JA, SE 7116/JA, SE 7122/JA, SE 7188/JA, SE 7202/JA, SE 7410/JA e SE 7434/ JA, SE $6969 / \mathrm{JA}$.

:24 Assim SE 734/JA, Min. Matco Aurélio, DJ 01/08/2002, p.0141, julgamento 08/07/2002, in MARQUES/JACQUES/SCHMIDT, p. 176-178. 
Nestes 17 casos estavam presentes as tradução, "a notícia do trânsito em julgado" e o documento original de registro administrativo de um prefeito ou de um administrador local, que segundo o STF "equivale à sentença irrecorrível" (SE 5125/JA) ${ }^{125}$. O Presidente do STF, citando os precedentes da Dinamarca (SE 1943), Bélgica (SE 2626) e vários do Japão (SE 1312, SE 2891-3, SE 3298-8, SE 3371-2, SE 3372-1, SE 1742), e com parecer do Ministério Público Federal pelo deferimento ao interpretar cumpridas as formalidades (Art. 102,I,h, CPC e RISTF), decidiu da seguinte forma:

"Defiro o pedido formulado e bomologo, para que surta eficácia no Brasil, o ato mediante o qual os requerentes divorciaram-se. 3. Expeça-se a carta de sentença. 4. Publique-se."126

Nestes 17 casos, porém, encontramos 5 casos com decisão do Presidente diferenciada. Em 3 casos (SE 6527/JA, SE 6882/JA e SE 6969/JA), é a mulher que requer sozinha a homologação frente ao STF. Em um destes casos (SE 6969/JA), o marido comparece ao STF para declarar que não se opõe à homologação, ${ }^{127}$ mas nos outros dois casos foi realizada a citação por edital do cônjuge varão e concedido-lhe curador especial que não se opôs à homologação. ${ }^{128}$ Aqui observa-se o interesse na mulher japonesa ou descendente de japoneses, com domicílio no Brasil, de ver homologado seu divórcio 'amigável' japonês no Brasil, para que surta todos os efeitos.

Interessante observar que no caso da SE 7410/JA, a divorcianda mulher requereu, frente ao STF, também a mudança de seu notne. ${ }^{129}$ Como esta altetação de nome não constava do registro administrativo japonês e o STF manteve sua linha de não admitir a extensão do processo delibatório, o pedido de bomologação foi deferido, mas sem modificação do nome, uma vez que: " $A$ modificação de nome não compóe a certidão." 131"

Também interessante é um caso mais antigo, anterior à Constituição de 1988, enquanto vigotava o Art. 38 da Lei de Divórcio (Lei 6.515/1977), o qual proibia o segundo divórcio do cônjuge brasileiro. Neste caso da SE 3869/JA, tratava-se do reconhecimento dos dois divórcios entre os mesmos cônjuges, um cônjuge brasileiro e um japonês. O STF homologou o primeiro divórcio sem restrições e homologou o segundo divórcio administrativo japonês

\footnotetext{
125 SE 5125/JA, Min. Sepúlveda Pertence, j. 23.11.97, in MARQUES/JACQUES/SCHMIDT, p. 204. ${ }^{126}$ Assim SE 6848/JA, Min. Marco Aurélio, DJ 06/09/2001, p.00030, julgamento 28/08/2001, in MARQUES/JACQUES/SCHMIDT, p. 195-197.

${ }^{127}$ SE 6969/JA, Min. Marco Aurélio, j. 21.09.2001, in MARQUES/JACQUES/SCHMIDT, p. 194. 195.

${ }^{12 \gamma}$ SE $6882 /$ Ja, Min. Marco Aurélio, j. 04.04.2002, in MARQUES/JACQUES/SCHMIDT, p. 183 e 184 e SE 527/JA, Min. Marco Aurélio, j. 13.09.2001, in MARQUES/JACQUES/SCHMIDT, p. 197 a 199.

${ }^{12 !}$ SE 7410/JA, Min. Macro Aurélio, j. 06.06.2002, in MARQUES/JACQUES/SCHMIDT, p. 179a 181.

${ }^{130}$ SE $7410 / \mathrm{Ja}$, in MARQUES/JMCQUES/SCHMIDT, p. 181.
} 
com eficácia irrestrita para o cônjuge japonês e considerou o cônjuge brasileiro apenas ‘separado judicialmente. ${ }^{134}$ Certa estava Ana Maria Villela, ${ }^{132}$ quando afirmava que a lacunosa e conservadora lei brasileira de divórcio de 1977 traria muitos problemas em direito intetnacional privado para o Brasil! Após 1988, a decisão foi revista.

Os problemas, porém, com a lei do divórcio não cessaram com a Constituição Federal de 1988, ao contrário, esta impôs como imperativos os prazos da Lei brasileita para o reconhecimento de divórcio de brasileiros, mesmo que declarados no exterior. Sendo assim encontramos na SE $7202 / \mathrm{JA}^{133}$ um caso do divórcio administrativo japonês de dois brasileiros, tesidentes no Japão, que foi reconhecido pelo STF, mas com eficácia apenas passado o prazo do Art. 226, $\$ 6^{\circ}$ da CF/1988, considerando-se ambos, no Brasil até aquela data como 'separados judicialmente'. A ementa da decisão é a seguinte:

"Defroopedidoformulado e bomologo, com a nestrição de queo ato medianteoqual os requerentes divorciaram-se somente produzirá efeitos plenos a partir de 05 de março de 2002 (Ant. 226, $\$ 6^{\circ}$ da Constituição Federal), observando-se, atéessa data, o instituto da separação judicial. ${ }^{\text {"34 }}$

Resta, pois, a dúvida se o 'elemento de conexão' indireto da nacionalidade, continua a reger o sistema de homologação de sentenças de divórcio no Brasil. Em outras palavtas, o STF utilizou o Art. $7^{\circ}, \$ 6^{\circ}$ da Lei de Introdução interpretado de acordo com os prazos do Art. $226, \$ 6^{\circ}$ da $\mathrm{CF} / 88$ e manteve a tradição brasileira desde 1977 de imperatividade dos prazos de separação de fato ou judicial para a concessão do divórcio.

\section{O EXAME DOS OUTROS CASOS}

Os outros 10 casos levantados em nossa pesquisa versam 5 sobre cartas rogatórias de citação de cônjuges no Brasil e Japão (CR 9772/JA, CR 9965/JA, CR 10091/JA, CR 9677/JA e PET 1582/SP), de 4 ditas 'sentenças' japonesas de divórcio e uma sentença paraguaia. Destes casos, 8 forma concedidos e 2 negados.

\footnotetext{
13! SE 3869/JA, Min. Rafael Mayer, j. 12.04.1988, in MARQUES/JACQUES/SCHMIDT, p. 215-216. ${ }^{1, \hat{2} 2}$ Assim as conclusões de VILLELA, p. 83 e seg.

${ }^{13.3} \mathrm{SE} 7202 /$ JA, Min. Marco Aurélio, j, $01 / 02 / 2002$, in MARQUES/JACQUES/SCHMTDT, p. 187188.

134 SE 7202/JA, in MARQUES/JACQUES/SCHMIDT, p. 188.
} 
As 4 cartas rogatórias passivas vindas do Japão referem-se à citação da mulher (CR 9965/JA, CR 9677/JA) ou do marido (CR 10091/JA e CR 9772/JA) no Brasil. ${ }^{135}$ Nestas 4 decisões, o STF examina se houve ou não ofensa à nossa ordem pública pelo fato de um brasileiro, esposa ou marido, estar respondendo uma 'ação de divórcio' frente a um Tribunal de Familia no Japão e conclui que não há ofensa, pois a competência é concorrente. Interessante é a CR 9677/JA, em que a esposa brasileira é citada para uma audiência -um ano antes- no Tribunal de Família- no Japão e ela mesmo havia entrado com um divórcio litigioso no foro de Piracicaba, em São Paulo. ${ }^{136}$ Como o STF não considerou exclusiva a competência do foro brasileiro na decisão de 2001 e concedeu o exequatur, em 2002, a esposa entrou com uma segunda 'alegação' de que ofenderia a nossa ordem pública tal 'divórcio' judicial no Japão, pois o casamento tinha acontecido no Brasil, em 1988 e sob a égide do direito brasileiro. Nenhum destes argumentos sensibilizou o STF, que manteve a citação e conclui que não havia qualquer ofensa à nossa ordem pública. A quinta Carta Rogatória é ativa, em que juiz de São Paulo requer ao STF a citação de cônjuge domiciliado no Japão. Nesta PET 1582/SP, o STF conclui que não é necessário passar as cartas rogatórias ativas pelo STF e nega o pedido que deve ser encaminhado diretamente ao Ministério da Justiça. ${ }^{137}$

Dos outros 4 casos, todos homologados pelo STF, há menção de sentença 'do Tribunal de Família. Em um caso houve renúncia de alimentos para a esposa e regulação expressa da guarda dos filhos (SE 4852/JA). ${ }^{138}$ Em um outro, SE 5608/JA, a esposa é brasileira e o marido japonês foi citado apenas por edital, mas o STF considerou cumpridas as exigências processuais e concedeu ao marido curador especial, ${ }^{139}$ sendo a homologação concedida. Nas SE 7292/JA e SE 7047/JA parece ter havido 'mediação'. O caso da SE 7047/JA é mais interessante, pois houve partilha de bens, inclusive de imóvel no Brasil, o que -em princípio- contraria o disposto nos Art. 12 da LICC e Art. 89 do CPC, pois seria caso de competência exclusiva do judiciário brasileiro. Mesmo assim o STF concedeu a homologação, alegando que o divórcio por

\footnotetext{
${ }^{135}$ CR 9965/JA, Min. Marco Aurélio, j. 04.02.2002, in MARQUES/JACQUES/SCHMIDT, p. 208 e 209, CR 9677/JA, Min. Maxco Aurélio, j.19.03.2002 e CR 9677/JA, Min. Carlos Velloso, j. 21.03.2001, in MARQUES/JACQUES/SCHMIDT, p. 205-206 e 206-207, CR 10091/JA, Min. Marco Aurélio, j. 18.03.2002, in MARQUES/JACQUES/SCHMIDT, p. 208 e CR 9772/JA, Min. Marco Aurélio, j. 07.08.2001, in MARQUES/JACQUES/SCHMIDT, p. 209 e 210.

t36 CR 9677/JA, Min. Marco Aurélio, 1.19.03.2002 e CR 9677/JA, Min. Carlos Velloso, j. 21.03.2001, in MARQUES/JACQUES/SCHMIDT, p. 205-206 e 206-207.

${ }^{137}$ PET 1582/SP, Min. Celso de Mello, j. 10.02.1999, in MARQUES/JACQUES/SCHMIT, p. 210 a 213 .

${ }^{138}$ SE 4852, Min. Otávio Gallotti, j. 18.08.1991, in MARQUES/JACQUES/SCHMIDT, p. 215.

${ }^{139} \mathrm{SE} 5608 / \mathrm{JA}$, Min. Celso de Mello, j. 18.11.1997, in MARQUES/JACQUES/SCHMIDT, p. 202 e 203.
} 
'mediação' era consensual e teria havido 'acordo sobre imóvel existente no Brasil', o que seria possivel. ${ }^{140}$

Mencione-se, por fim, um outro caso sui generis levantado de divórcio de japoneses domiciliados no Brasil, mas realizado em foro 'facilitatório' do Paraguai. Neste caso de 1979 (SE 2446), a homologação foi recusada tendo em vista a competência 'absoluta' do juízo brasileiro. ${ }^{141}$

Como se observa, a visão do STF dos divórcios obtidos no Japão é bastante positiva e aberta, com forte tendência a superar qualquer obstáculo formal.

\section{CONCLUSÕES}

Certa a saudosa professora da UnB, Anna Maria Villela, que o controle exercido pelo STF em matéria de homologação de sentenças estrangeiras de divórcio é 'um controle puramente formal ou exterior da decisão estrangeira". ${ }^{142}$ As decisões anteriores à 1977, oriundas dos páses nórdicos, como Noruega, Dinamarca e outros, que conhecem decisões administrativas de divórcio, bem demonstram que realmente o STF procura respeitar estes tipos e estas 'formalidades' de concessão do divótcio dos países de origem destas. Já os divórcios religiosos são mais controlados, no que se refere aos direitos fundamentais das mulheres e à ofensa eventual a nossa ordem pública. ${ }^{33}$

Conclui-se que o divórcio japonês registrado frente a um oficial administrativo é visto pelo STF mais como uma formalidade, do que como um momento de fundo e o controle exercido é meramente formal, procurando respeitars as diferenças culturais. Os alertas dos professores japoneses e estudos como estes podem servir para levar à evolução da posição do STF.

A verdade é que a posição do STF já parece bastante condizente com o momento atual de liberdade dos indivíduos e de circulação de decisões de divórcios, criando maior harmonia e permitindo o reconhecimento das novas famílias formadas após o divórcio em um dos países. Sendo assim, se bem que considero importante a precisão de que se tratam de meros atos privados, registrados no oficial administrativo do distrito, mister considerar que se este tipo de divórcio japonês equivale a mais de $90 \%$ do divótcio no

\footnotetext{
140 SE 7047/JA, Min. Macro Aurélio, j. 25.06.2002, in MARQUES/JACQUES/SCHMIDT, p. 178 a 179.

${ }^{141}$ SE 2446/JA, Min. Antônio Neder, j. 19.11.1979, in MARQUES/JACQUES/SCHMiDT, p. 218. 219.

142 VILLELA, p. 13.

${ }^{143}$ Assin repudiação islâmica, não homologada pelo STF, citada por BASSO TAMAGNO, p. 84 e por Valladão, III, p. 134 (SE 2574/Jordânia, j. 05.11.1980).
} 
pás, a significar que é a forma de dissolução do casamento culturalmente mais aprovada pela população japonesa. A regra de reconhecerem-se tais divórcios parece, pois, contribuir ao entendimento entre Brasil e Japão e a movimentação dos imigrantes e descendentes entre estes países. As exceções, quando o cônjuge mulher, por exemplo, não tiver realmente consentido ou a declaração the tiver retirados direitos, podem ser resolvicias através de um. exame mais detalhado no sistema da Sentença Estrangeira contestada, ${ }^{144}$ no Brasil, pela prejudicada.

Por fim, faço minhas as palavras do mestre Erik Jayme: "O direito de família em uma sociedade pluricultural, se visamos reconhecer um direito da pessoa à proteção de sua identidade cultural, necessita de uma certa 'personalização' das respectivas regras para resolver os conflitos de leis." 44 Concluo , pois, louvando a linha de nosso Supremo Tribunal Federal, que soube tratar 'diferentemente os diferentes', com tolerância cultural e 'personalização' para proteger os interesses dos imigrantes e descendentes de japoneses no Brasil, soube sobretudo respeitar as diferenças culturais de ambos os países e fomentar a harmonia de decisões entre Brasil e Japão!

\footnotetext{
i44 Veja contestação da sentença estrangeira e processo de 'impugnação', nos Artigos 220,221 e 223 do Regimento do Supremo Tribunal Federal in NERY/NERY, CPC Comentado, p. 1822 e 1823.

${ }^{145}$ No original em italiano, Jayme, Società multiculturale, p. 356: "Il dirieto di famiglia in una società pluriculturale richiede, se si cerca di riconoscete un dirito della persona alla protezione della sua identità culturale, una certa 'personalizzazione' delle rispettive regole per risolvere i conflitti di leggi."
} 